\title{
Lack of Neurotrophin-4 Causes Selective Structural and Chemical Deficits in Sympathetic Ganglia and Their Preganglionic Innervation
}

\author{
Alexander Roosen, ${ }^{1}$ Andreas Schober, ${ }^{1}$ Jens Strelau, ${ }^{1}$ Martina Böttner, ${ }^{1}$ Jörg Faulhaber, ${ }^{2}$ Gerald Bendner, ${ }^{1}$ \\ Sabrina L. Mcllwrath, ${ }^{4}$ Horst Seller, ${ }^{2}$ Heimo Ehmke, ${ }^{3}$ Gary R. Lewin, ${ }^{4}$ and Klaus Unsicker ${ }^{1}$ \\ ${ }^{1}$ Department of Neuroanatomy and Interdisciplinary Center for Neuroscience and 2Department of Physiology, University \\ of Heidelberg, D-69120 Heidelberg, Germany, ${ }^{3}$ Department of Physiology, University of Hamburg, D-20251 Hamburg, \\ Germany, and ${ }^{4}$ Max-Delbrück-Center for Molecular Medicine, D-13122 Berlin-Buch, Germany
}

\begin{abstract}
Neurotrophin-4 (NT-4) is perhaps the still most enigmatic member of the neurotrophin family. We show here that NT-4 is expressed in neurons of paravertebral and prevertebral sympathetic ganglia, i.e., the superior cervical (SCG), stellate (SG), and celiac (CG) ganglion. Mice deficient for NT-4 showed a significant reduction (20-30\%) of preganglionic sympathetic neurons in the intermediolateral column (IML) of the thoracic spinal cord. In contrast, neuron numbers in the SCG, SG, and $\mathrm{CG}$ were unchanged. Numbers of axons in the thoracic sympathetic trunk (TST) connecting the SG with lower paravertebral ganglia were also reduced, whereas axon numbers in the cervical sympathetic trunk (CST) were unaltered. Axon losses in the TST were paralleled by losses of synaptic terminals on SG neurons visualized by electron microscopy. Furthermore, immunoreactivity for the synaptic vesicle antigen SV2 was clearly reduced in the SG and CG. Levels of catecholamines and tyrosine hydroxylase immunoreactivity were dramatically re-
\end{abstract}

Neurotrophins are a family of growth factors with important functions in the control of neuron survival and differentiation (Barde, 1989; Davies, 2000). The prototypic member of the neurotrophins is nerve growth factor (NGF), which was discovered $>50$ years ago and is instrumental in shaping the neurotrophic factor concept (Levi-Montalcini, 1987). The classic neurotrophic factor concept describes ontogenetic neuron death or survival, respectively, as a function of proteins that are synthesized and released by neuronal target cells and act retrogradely on the neuronal cell body by stimulating survival and differentiation machineries. There is overwhelming evidence that this concept oversimplifies reality in many directions, e.g., by not taking into account the diversities of sources, mechanisms, actions, and cooperativities of neurotrophic molecules (Korsching, 1993). Brain-derived neurotrophic factor (BDNF) and neurotrophin-3 were discovered in the 1980s (Leibrock et al., 1989; Maisonpierre et al., 1990) and assigned diverse functional roles in neuron development (Snider, 1994) and synaptic plasticity (McAllister et al., 1999).

\footnotetext{
Received July 14, 2000; revised Feb. 7, 2001; accepted Feb. 8, 2001.

This work was supported by Deutsche Forschungsgemeinschaft Grant SFB 488, TP a6. We thank Barbara Brühl and Richard Hertel for excellent technical assistance.

A.R. and A.S. have contributed equally to this work.

Correspondence should be addressed to Dr. Andreas Schober, Department of Neuroanatomy, University of Heidelberg, Im Neuenheimer Feld 307, D-69120 Heidelberg, Germany. E-mail: andreas.schober@urz.uni-heidelberg.de.

Copyright (C) 2001 Society for Neuroscience 0270-6474/01/213073-12\$15.00/0
}

duced in the SG and the CG but not in the SCG. Despite this severe phenotype in the sympathetic system, blood pressure levels were not reduced and displayed a pattern more typical of deficits in baroreceptor afferents. Numbers of IML neurons were unaltered at postnatal day 4 , suggesting a postnatal requirement for their maintenance. In light of these and previous data, we hypothesize that NT-4 provided by postganglionic sympathetic neurons is required for establishing and/or maintaining synapses of IML neurons on postganglionic cells. Impairment of synaptic connectivity may consequently reduce impulse flow, causing a reduction in transmitter synthesis in postganglionic neurons.

Key words: preganglionic sympathetic neurons; intermediolateral column; superior cervical ganglion; stellate ganglion; celiac ganglion; synapses; catecholamines; brain-derived neurotrophic factor
Neurotrophin-4 (NT-4) is probably the least well understood neurotrophin and distinct from other neurotrophins in several respects (for review, see Ibánez, 1996). It is the most divergent member of the neurotrophin family, almost ubiquitously expressed, and the only one whose inactivation by gene targeting is not lethal during early postnatal development. NT-4 knock-out mice show an $\sim 50 \%$ loss of nodose-petrosal and geniculate sensory neurons (Conover et al., 1995; Liu et al., 1995; Erickson et al., 1996), with no apparent losses occurring in dorsal root ganglia. However, NT-4 is required for the survival of a subclass of hair follicle receptors (Stucky et al., 1998). NT-4 and BDNF signal via the same high-affinity TrkB receptor (Ip et al., 1993; Barbacid, 1994). However, mice deficient in NT-4 show sensory deficits that display only partial overlap with deficits noted in $B D N F$ mouse mutants. This is consistent with previous studies that have shown different biological effects of NT-4 and BDNF in the visual (Riddle et al., 1995) and dopaminergic nigrostriatal (Hyman et al., 1994) systems. Apparently, NT-4 and BDNF also activate partially distinct signal transduction cascades, as shown by the mutation of the shc adaptor binding site in the $\operatorname{trk} B$ gene (Minichiello et al., 1998).

We and others (Causing et a., 1997; Schober et al., 1998) have shown previously that preganglionic sympathetic neurons located in the intermediolateral column (IML) of the spinal cord express $\operatorname{TrkB}$. Mice deficient for $\operatorname{Trk} B$ show severe ultrastructural alterations in axon terminals on adrenal chromaffin cells, a major population of target cells for IML neurons (Schober et al., 1998), 
but die too early for studying putative cell losses in the IML neuron population. NT-4-deficient mice surviving into adulthood display a modest loss of IML neurons projecting to the adrenal medulla, suggesting a partial requirement for NT-4. The present study provides evidence that NT-4 is not only expressed by adrenal chromaffin cells but also by sympathetic postganglionic neurons and that IML neurons throughout the spinal cord axis, their axon terminals, and postganglionic neurons are severely affected in NT-4 mouse mutants.

\section{MATERIALS AND METHODS}

Animals. Forty-five adult NT-4 (-/-) mice (129/Sv) and 35 corresponding wild-type mice of the same genetic background (RCC Ltd., Füllinsdorf, Switzerland) were used. They were kept under standard laboratory conditions with food and water available ad libitum and a $12 \mathrm{hr}$ light/dark cycle. In addition, two litters each of both knock-out and wild-type mice at age postnatal day $4(\mathrm{P} 4)$ were used. In situ hybridization experiments were performed with eight adult Hanover-Wistar female rats (250 gm).

Fluoro-Gold labeling, tissue preparation, and quantitative analysis. It has been shown previously that intraperitoneal injection of the fluorescent tracer Fluoro-Gold (FG) labels the entire population of viable sympathetic preganglionic (IML) neurons in the spinal cord (Anderson and Edwards, 1994). Forty-eight hours after intraperitoneal injection of 150 $\mu \mathrm{l}$ of FG (0.2\%; Fluorochrome Inc., Englewood, NJ), animals were deeply anesthetized with diethylether and transcardially perfused with freshly prepared $4 \%$ paraformaldehyde (PFA). Thereafter, the whole thoracic spinal cord was exposed, and spinal cord segments T1-T5 and T10-T12 were removed. These spinal cord segments contain the majority of preganglionic neurons for the superior cervical (SCG) and stellate (SG) ganglion, and for the celiac/superior mesenteric ganglion complex (CG), respectively (Strack et al., 1988; Pyner and Coote, 1994) (Fig. 1B). After $12 \mathrm{hr}$ of post-fixation (4\% PFA), longitudinal serial sections of the spinal cord at a thickness of $30 \mu \mathrm{m}$ were performed on a vibrating blade microtome (VT 1000 E; Leica, Nussloch, Germany), collected freefloating, and mounted on chrom-alum-subbed slides. Sections were examined bilaterally by a Zeiss (Oberkochen, Germany) Axiophot fluorescent microscope using an UV filter set (excitation filter, 390-420 nm; barrier filter, $425-450 \mathrm{~nm}$; Zeiss). We only counted brightly fluorescent cells with a clearly visible nucleus, restricted to the lateral funiculus (LF) and IML, in which $97 \%$ of preganglionic sympathetic neurons are located (Strack et al., 1988; Pyner and Coote, 1994). Total numbers were corrected for possible double counts of split nuclei according to Abercrombie's formula (Konigsmark, 1970). Results are given as mean \pm SEM values in percent and tested for statistical significance of differences by Student's $t$ test.

Immunohistochemistry. NT-4 $(+/+)$ and $(-/-)$ mice were anesthetized and transcardially perfused with $4 \%$ PFA. The following tissues were removed: the SCG and SG, the CG, and adrenal glands. Tissues were then post-fixed for $1 \mathrm{hr}$ and either processed for paraffin embedding or cryoprotected overnight ( $15 \%$ sucrose). The following primary antibodies were used: polyclonal anti-NT-4 (not cross-reactive with BDNF; Chemicon, Temecula, CA), polyclonal anti-tyrosine hydroxylase $(\mathrm{TH})$ (Chemicon), and monoclonal anti-SV2 (a kind gift from Dr. E. Stöckli, Basel, Switzerland). For NT-4 immunolabeling, cryoprotected tissues were cut on a cryostat $(10 \mu \mathrm{m})$. Sections were then mounted on chromalum-coated slides, dried at room temperature for $30 \mathrm{~min}$, and placed in $0.1 \mathrm{~m}$ phosphate buffer (PB), $\mathrm{pH}$ 7.4. After nonspecific blocking with 5\% normal goat serum (diluted in PB, $0.1 \%$ Triton X-100) for $1 \mathrm{hr}$ at room temperature, sections were incubated with the primary antibody, diluted 1:500, for $24 \mathrm{hr}$ at room temperature. Slides were washed three times for 5 min each in $\mathrm{PB}$, and binding of primary antibody was visualized using a biotin-conjugated anti-rabbit $\operatorname{IgG}(1: 200,2 \mathrm{hr}$ at room temperature; Vector Laboratories, Burlingame, CA). Slides were then washed as before and incubated with Cy3-conjugated streptavidin (indocarbocyanine; Jackson ImmunoResearch, West Grove, PA) for another $2 \mathrm{hr}$ at room temperature (diluted 1:2000). For TH immunostaining, deparaffinized sections $(7 \mu \mathrm{m})$ and cryosections $(10 \mu \mathrm{m})$ were washed in PBS, $\mathrm{pH} 7.4$, and preincubated in $10 \%$ rabbit serum (PBS), containing $0.1 \%$ Triton X-100, for $1 \mathrm{hr}$ at room temperature. Slides were washed three times for 3 min each in PBS and then marked overnight at $4^{\circ} \mathrm{C}$ with primary antibody, diluted 1:500 in $10 \mathrm{ml}$ of PBS $-100 \mu \mathrm{l}$ of BSA-5 $\mu \mathrm{l}$ of Triton X-100. Sections were washed as before and incubated with biotinconjugated anti-sheep IgG (Vector Laboratories) at a dilution of 1:100 for $1 \mathrm{hr}$ at room temperature. Slides were washed again, and staining was visualized using Cy2- or Cy3-conjugated streptavidin (1:2000, room temperature, $1 \mathrm{hr}$; Jackson ImmunoResearch). SV2 immunohistochemistry was similar to $\mathrm{TH}$ staining described above, with the exception that for nonspecific blocking, normal horse serum was used, and the primary antibody was diluted 1:100 and visualized directly with $\mathrm{Cy} 3$-conjugated anti-mouse $\operatorname{IgG}(1: 1000$, room temperature, $2.5 \mathrm{hr}$; Jackson ImmunoResearch).

Cell counts of postganglionic sympathetic neurons. SCG, SG, and CG were embedded in paraffin, serial sections at a thickness of $7 \mu \mathrm{m}$ were performed, and every fifth section was collected and mounted on gelatincoated slides. Slides were Nissl-stained with cresyl violet. For SCG, the total neuron number was determined according to Coggeshall et al. (1984). Because SG and CG are often merged to adjacent ganglia making definition of borders difficult, we determined neuronal density for these ganglia. Neurons were counted within a defined area of $180 \times 180 \mu \mathrm{m}^{2}$.

Determination of IML neuron numbers by AChE and Nissl staining. Nissl-stained cryostat sections of P4 mice thoracic spinal cord [NT-4 $(-/-), n=3 ; N T-4(+/+), n=3$; segments T1-T5], as well as adult mice spinal cord [NT-4 (-/-), n=3;NT-4 (+/+), $n=3$; segments T10-T12] were used for determining numbers of sympathetic preganglionic neurons (100 adjacent cross-sections per animal, $20 \mu \mathrm{m})$. To identify IML neurons reliably, we counterstained Nissl-stained sections weakly by AChE histochemistry (Andrä and Lojda, 1986). Sections were stained for $45 \mathrm{~min}$ at $37^{\circ} \mathrm{C}$ in the following solution $(60 \mathrm{ml}): 30.0 \mathrm{mg}$ of acetylthiocholine iodide (Serva Feinbiochemica, Heidelberg, Germany), 44.4 $\mathrm{ml}$ of $0.1 \mathrm{~m}$ Tris-maleate buffer, $\mathrm{pH} 5.0$ (containing $0.1 \%$ Triton X-100), $6.0 \mathrm{ml}$ of $0.4 \mathrm{M}$ sodium citrate, $6.0 \mathrm{ml}$ of $0.12 \mathrm{M}$ copper citrate, $3.0 \mathrm{ml}$ of $0.16 \mathrm{M}$ potassium ferricyanide, and $0.6 \mathrm{ml}$ of $10^{-3} \mathrm{M}$ tetraisopropylpyrophosphoramide (iso-OMPA; Sigma, St. Louis, MO). Sections from knock-out and wild-type animals were always processed in parallel. Neurons were counted within an area of $120 \times 240 \mu \mathrm{m}^{2}$ for P4 mice and within an area of $240 \times 240 \mu \mathrm{m}^{2}$ for adult mice.

Electron microscopy. Animals were perfused with 4\% PFA, and the SCGs, SGs, and the CG were removed. SCGs and SGs were taken with $\sim 1 \mathrm{~mm}$ of attached cervical sympathetic trunk (CST) or the thoracic sympathetic trunk (TST), entering the ganglia at their caudal poles. Samples were post-fixed for $24 \mathrm{hr}$ in $1.5 \%$ glutaraldehyde and $1.5 \%$ PFA in $\mathrm{PB}$ and embedded in Epon according to standard protocols. Thin sections were collected on Formvar-coated 75 mesh copper grids (Pelco, Redding, CA), stained with $5 \%$ uranylacetate, followed by lead citrate, and examined and photodocumented using a Zeiss electron microscope (EM10A). Cross sections of the CST and TST were used for analyzing numbers of axons.

Cross-sections of the SG were used for examining numbers of synaptic terminals and average length of presynaptic and postsynaptic membrane specializations. In addition, numbers of lysosomes were counted in postganglionic cell bodies and dendrites. Complete cross-sections from five levels of an NT-4 (+/+) and an NT-4 (-/-) SG were examined.

Determination of catecholamine content. NT-4 $(+/+)$ and $(-/-)$ mice were killed rapidly by $\mathrm{CO}_{2}$ intoxication. Adrenal glands, SCGs, and the CG were quickly removed. Catecholamines were quantified by HPLC as described by Müller and Unsicker (1981). Statistical significance was determined by Student's $t$ test.

$R N A$ preparation and reverse transcription- $P C R$. Reverse transcription (RT)-PCR was used to determine the expression of NT-4 and BDNF transcripts in sympathetic ganglia (SCG, SG, and CG) of adult wild-type and $N T$-4-deficient mice. For NT-4 control experiments, mRNA expression in skeletal muscle of wild-type and NT-4 knock-out mice was analyzed. BDNF amplification was verified by using cerebellar tissue of wild-type animals. Mice were killed by $\mathrm{CO}_{2}$ intoxication, ganglia were quickly removed, and total RNA was isolated from tissues using Trizol (Life Technologies, Karlsruhe, Germany) according to the manufacturer's guidelines. RNase inhibitor (2 U; MBI Fermentas, St. Leon-Rot, Germany) and 1 U of RQ1 DNase (Promega, Mannheim, Germany) was added to $1 \mu \mathrm{g}$ of total RNA in a final volume of $12 \mu \mathrm{l}$. Reactions were incubated for $15 \mathrm{~min}$ at $37^{\circ} \mathrm{C}$ and $5 \mathrm{~min}$ at $80^{\circ} \mathrm{C}$. First-strand cDNA was synthesized in a final volume of $40 \mu \mathrm{l}$. Reactions consisted of $1 \mu \mathrm{g}$ of total RNA and final concentrations of $1 \times$ first strand buffer $[5 \times$ first-strand buffer: $250 \mathrm{~mm}$ Tris-HCl, pH 8.3, $375 \mathrm{~mm} \mathrm{KCl,} 15 \mathrm{~mm} \mathrm{MgCl} 2$ (Life Technologies)], $10 \mathrm{~mm}$ dithiothreitol (DTT), and $1 \mathrm{~mm}$ each of dNTPs (Promega), $25 \mathrm{ng} / \mu \mathrm{l}$ random hexamer primers (Promega), $1 \mathrm{U} / \mu \mathrm{l}$ RNase inhibitor (MBI Fermentas), and $20 \mathrm{U} / \mu \mathrm{l}$ Moloney murine leukemia virus reverse transcriptase (Life Technologies). The reaction mixture was incubated at $37^{\circ} \mathrm{C}$ for $2 \mathrm{hr}$, heated for $5 \mathrm{~min}$ at $90^{\circ} \mathrm{C}$, cooled to $4^{\circ} \mathrm{C}$ for 5 


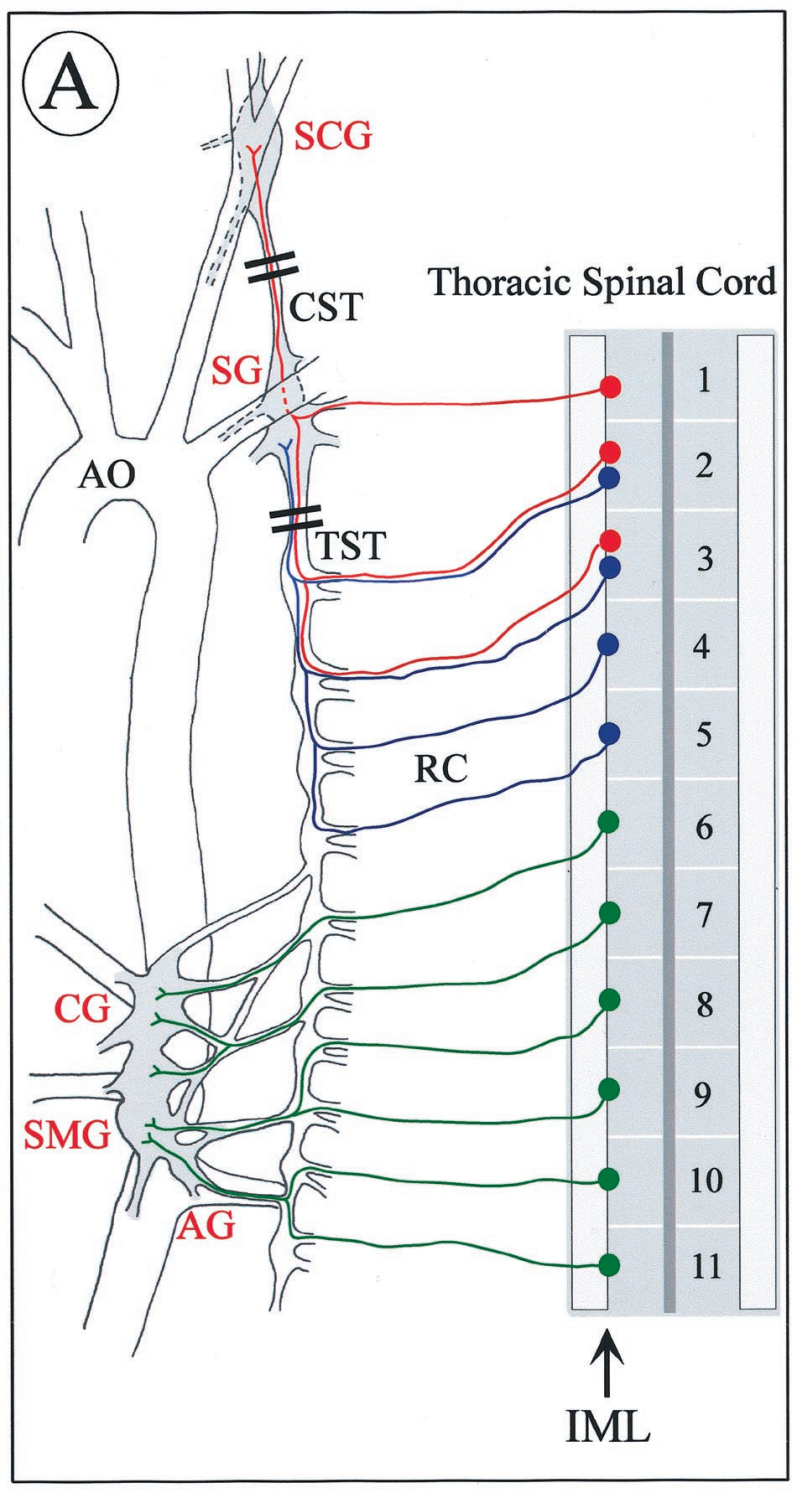

Segmental distribution of IML-neurons

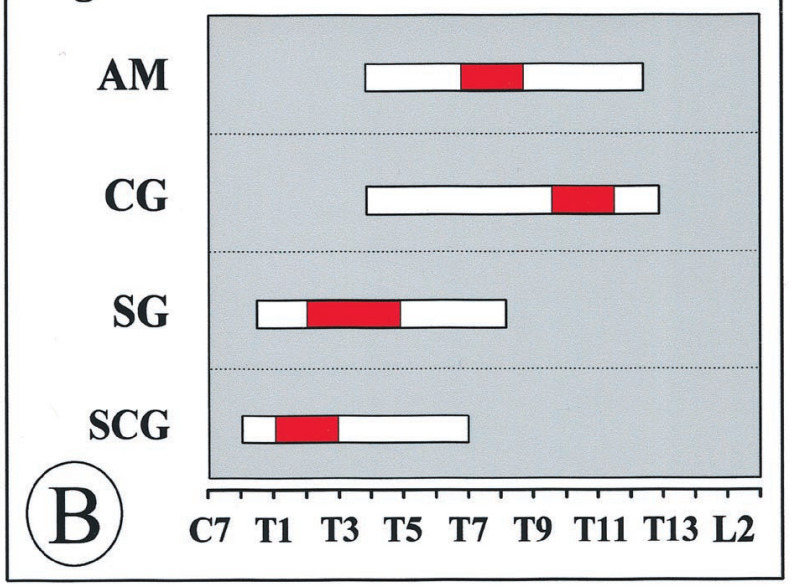

Figure 1. Anatomy of preganglionic and postganglionic structures in the sympathetic nervous system relevant to the present study $(A)$. Cell bodies of preganglionic neurons are located in the IML at distinct levels of the spinal cord and project through rami communicantes $(R C)$ to paravertebral and prevertebral sympathetic ganglia. We have analyzed IML neurons at levels T1-T5 that project to the paravertebral SCG and the SG, min, and supplemented with $2 \mathrm{U}$ of RNase $\mathrm{H}$ (Life Technologies). Samples were incubated $20 \mathrm{~min}$ at $37^{\circ} \mathrm{C}$.

After reverse transcription, cDNA samples were subjected to PCR amplification using specific primers based on the mouse sequences for NT-4 and $B D N F$. The $N T-4$ forward and reverse primers (5'-CCCAAGTTGA-

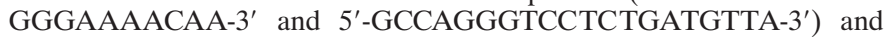
the BDNF-specific oligonucleotides (5'-GCCCAACGAAGAAAACCATA-3' and 5'-TCAGTTGGCCTTTGGATACC-3') amplify PCR products of $299 \mathrm{bp}$. Forward and reverse primers for amplification of $\beta$-actin cDNA (Genembl accession number J00691) were 5'-TCATGAAGTGTGACGTTGACATCCGT-3' and 5'-CCTAGAAGCATTTGCGGTGCACGAT-3', respectively. Reactions were performed in $0.2 \mathrm{ml}$ thin-walled reaction tubes in a Eppendorf Mastercycler Gradient thermocycler. Reagents were assembled in a final volume of $50 \mu \mathrm{l}$ with $6 \mu \mathrm{l}$ of first-strand cDNA, $2 \mu \mathrm{M}$ forward primer, $2 \mu \mathrm{M}$ reverse primer, $1 \times$ PCR buffer $[10 \times$ PCR buffer: $200 \mathrm{~mm}$ Tris-HCl, pH 9.0, and $500 \mathrm{~mm} \mathrm{KCl} \mathrm{(Promega)],} 2.5$ $\mathrm{mM} \mathrm{MgCl}$, and $0.1 \mathrm{~mm}$ each of dNTPs and RNase-free water to $49.5 \mu \mathrm{l}$. cDNA was denatured at $94^{\circ} \mathrm{C}$ for 5 min, after which the temperature was lowered to $72^{\circ} \mathrm{C}$. Taq DNA polymerase $(0.5 \mu \mathrm{l}, 2.5 \mathrm{U}$; Promega) was then added, and cDNAs were amplified for 32 and 36 cycles (NT-4 and BDNF) or 24 cycles $\left(\beta\right.$-actin; $\left.58^{\circ} \mathrm{C}\right)$. One round of amplification consisted of $30 \mathrm{sec}$ at $94^{\circ} \mathrm{C}, 30 \mathrm{sec}$ at $62^{\circ} \mathrm{C}$, and $30 \mathrm{sec}$ at $72^{\circ} \mathrm{C}$. PCR reactions $(12.5 \mu \mathrm{l})$ were run on agarose gels (Life Technologies) in $1 \times$ TAE buffer $(0.04 \mathrm{M}$ Tris-acetate and $0.001 \mathrm{M}$ EDTA), and reaction products were visualized after soaking gels in $0.5 \mu \mathrm{g} / \mathrm{ml}$ ethidium bromide solution in distilled water for $10 \mathrm{~min}$, with a transilluminator (Renner GmbH, Dannstadt, Germany). Pictures were taken by a computer-assisted gel documentation system (Intas, Göttingen, Germany). For semiquantitative analysis of $B D N F$ mRNA in wildtype and NT-4-deficient mice, $\beta$-actin was used as a standard. The same cerebellar BDNF PCR reaction was run on both gels and exhibits identical signal intensity, thus permitting a direct comparison of wild-type and NT-4 knock-out gels. BDNF signals of all three ganglia of four NT-4-deficient and four wild-type mice were semiquantified by computer software (NIH Image).

In situ hybridization. Adult Wistar rats were deeply anesthetized, and SCG, SG, and CG ganglia were removed and frozen on dry ice. Sections $(20 \mu \mathrm{m})$ were cut on a cryostat, thaw-mounted onto silane-coated slides, and stored at $-70^{\circ} \mathrm{C}$. Cryosections were then post-fixed for $10 \mathrm{~min}$ in $4 \%$ PFA and rinsed twice in PBS. Slides were incubated for 10 min with $1.5 \%$ triethanolamine, $0.33 \%$ acetanhydride, and $50 \mathrm{~mm} \mathrm{HCl}$, washed in PBS, and dehydrated. Air-dried sections were hybridized with $2 \times 10^{7} \mathrm{cpm}$ ${ }^{35} \mathrm{~S}$-labeled cRNA probe per $1 \mathrm{ml}$ of hybridization mixture $(50 \%$ formamide, $10 \%$ dextransulfate, $0.3 \mathrm{M} \mathrm{NaCl}, 5 \mathrm{~mm}$ EDTA, $20 \mathrm{~mm}$ Tris, $\mathrm{pH}$ $7.5,10 \mathrm{~mm}$ DTT, and $1 \mathrm{mg} / \mathrm{ml}$ yeast RNA) and hybridized overnight at $60^{\circ} \mathrm{C}$ in a humidified chamber. Riboprobes were derived from a pGEM-T plasmid (Promega) containing 249 bp of the rat NT-4 coding sequence (EMBL accession number RNNT4P) (Ip et al., 1992). The plasmid was linearized with appropriate restriction enzymes, and riboprobes were transcribed in the presence of ${ }^{35}$ S-UTP using SP6 polymerase (Promega) for preparing the antisense probe and T7 polymerase (Promega) for generating the sense probe. After hybridization, sections were washed three times for $30 \mathrm{~min}$ in $2 \times \mathrm{SSC}$ at room temperature and subsequently incubated for $30 \mathrm{~min}$ at $37^{\circ} \mathrm{C}$ with $20 \mu \mathrm{g} / \mathrm{ml}$ RNase A in $2 \times$ SSC. Slides were rinsed in $2 \times \mathrm{SSC}$ and washed three times for $30 \mathrm{~min}$ at $55^{\circ} \mathrm{C}$ in $50 \%$ formamide $-2 \times$ SSC, $2 \times$ SSC, and $0.2 \times$ SSC. After dehydration, sections were air-dried and dipped into LM-1 emulsion (Amersham Pharmacia Biotech, Piscataway, NJ), exposed for $8-12$ weeks at $4^{\circ} \mathrm{C}$, and developed according to the manufacturer's guidelines. Counterstaining was performed with hematoxylin-eosin.

Blood pressure measurements. Blood pressure was measured in six female wild-type $129 / \mathrm{Sv}$ mice and six NT-4 knock-out mice weighing

$\leftarrow$

respectively. IML neurons projecting to the prevertebral CG and the superior mesenteric ganglion $(S M G)$, which were also analyzed, cluster at spinal cord segments T10-T12. In our study, we did not make an attempt to separate the intimately associated CG and SMG; however, we did not include the aortorenal ganglion $(A G)$. The adrenal gland and its preganglionic neurons, which peak in the IML T7-T10, are not shown. $A O$, Aorta. Double bars through the CST and TST mark portions that were analyzed for numbers of axons. $B$ shows the distribution of IML neurons projecting to the adrenal medulla $(A M)$ and various ganglia along the spinal cord axis according to Strack et al. (1988). The red portion of the bar indicates the peak accumulation of IML neurons for the respective targets. 
Figure 2. Expression of NT-4 mRNA and protein revealed by RT-PCR $(A ; 36$ cycles), in situ hybridization $(I S H)$ of the CG $(D, E)$, and IR of the CG (C). $B$ shows a consecutive section to $C$ stained for TH. $A$, RT-PCR demonstrates expression of NT-4 mRNA in skeletal muscle (as a positive control) in the celiac, stellate, and superior cervical ganglion. Respective signals are absent in NT-4 mouse mutants. D, In situ hybridization shows that neuronal perikarya in the CG are prominent sites of expression of NT-4 $m R N A$. E, A higher magnifications reveals localization of grains over large neuronal cell bodies. $B, C, \mathrm{TH}$ - and NT-4-IR in consecutive sections of a CG reveal the presence of NT-4 protein in catecholaminergic sympathetic neurons. Scale bars: $B-D, 500 \mu \mathrm{m} ; E, 50 \mu \mathrm{m}$.

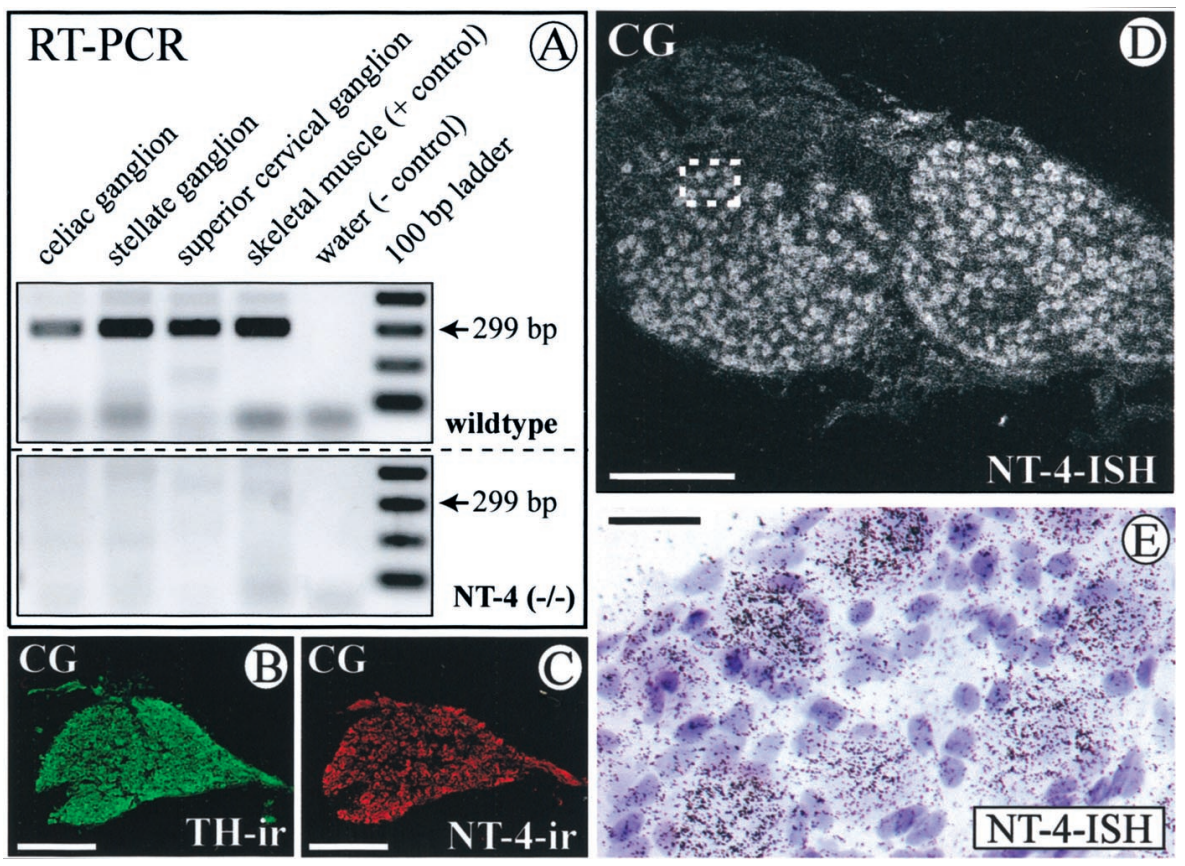

23-30 gm (age of 4-5 months). After surgery, the mice were housed individually in plastic cages. They had access to a standard mouse chow diet and tap water ad libitum. All experiments and procedures were done in accordance with the national law for the care and use of research animals.

Surgical procedures. For catheter implantation, the mice were anesthetized with ketamine and rompun $(100 \mathrm{mg} / \mathrm{kg}$ and $4 \mathrm{mg} / \mathrm{kg}$, i.p., respectively). Supplemental doses of ketamine were administered as needed. With the use of aseptic techniques, a catheter was placed in the left femoral artery for the measurement of arterial blood pressure. The catheter (diameter of $300-500 \mu \mathrm{m}$ ) was made as described previously by Mattson (1998). Catheters were tunneled subcutaneously and exteriorized through a $15 \mathrm{~cm}$ piece of lightweight spring; the tethering spring was attached to the back of the animal by sewing a 1-cm-diameter stainless steel button into the strap muscles between the scapulae. The free end of the spring was connected to a swivel device at the top of the cage. During and after surgery, the animals were kept warm and received a single dose of cefazoline (10 mg, i.v.). The mice were allowed to recover for at least $48 \mathrm{hr}$ after the surgery before the recordings were conducted. With this surgical procedure, the mice regain full use of the catheterized limb and moved easily throughout their cages. The catheters were filled with $50 \mathrm{U}$ of heparin in $1 \mathrm{ml}$ of saline, sealed, and only opened when they were used for measurements.

Measurements. Arterial blood pressure was recorded for $1 \mathrm{hr}$ in awake mice moving freely in their own cage on days 2 and 3 after surgery. Arterial blood pressure was measured by a pressure transducer (PRC21K; Keller) with a calibrated amplifier (Föhr Medical Instruments, Seeheim, Germany) connected to the arterial catheter. Arterial blood pressure data were continuously stored on a computer $(80586$ + Labtech Note Book V 10.2.1) at a sampling rate of $500 \mathrm{~Hz}$, after analog-to-digital conversion (model DAS-16; Keithly-Metrabyte, Tauton, MA).

\section{RESULTS}

\section{Paravertebral and prevertebral sympathetic ganglia express NT-4 mRNA and protein}

Having shown previously that virtually all preganglionic sympathetic (IML) neurons in the thoracic spinal cord express the neurotrophin receptor for both BDNF and NT-4, TrkB (Causing et al., 1997; Schober et al., 1998), we first investigated whether NT-4 was expressed in sympathetic ganglia to possibly act on IML neurons. Because paravertebral and prevertebral sympathetic ganglia differ significantly with regard to their requirement for the paradigmatic neurotrophin NGF (Thoenen, 1972; Smeyne et al.,
1994), we chose the SCG (Fig. $1 A$ ) and the SG (Fig. 1 $A$ ) as representatives of the paravertebral ganglia and the $\mathrm{CG}($ Fig. $1 A$ ) as representatives of the prevertebral ganglia. The distribution and peak accumulation of IML spinal cord neurons projecting to these ganglia is shown in Figure $1 B$ (cf. Strack et al., 1988). Figure $2 A$ demonstrates that all three sympathetic ganglia investigated contain NT-4 mRNA revealed by RT-PCR. Skeletal muscle, which is known to synthesize large amounts of NT-4 (Timmusk et al., 1993; Funakoshi et al., 1995; Griesbeck et al., 1995), was used as a positive control. In situ hybridization (Fig. 2D,E) confirms the presence of NT-4 mRNA in the CG and localizes grains predominantly to large neuronal cell bodies. NT-4 immunoreactivity (IR) is also detectable in neuronal cells (Fig. 2C) and colocalizes with $\mathrm{TH}$ (Fig. $2 B$ ), corroborating the notion that sympathetic neurons express NT-4 mRNA and protein. Similarly, NT-4 mRNA and IR were localized in neuronal cell bodies of SCG and SG (data not shown).

\section{IML neurons are decreased in adult NT-4-deficient mice}

To investigate the putative physiological role of NT-4 for the maintenance of preganglionic sympathetic neurons in the adult IML, we labeled the entire population of preganglionic sympathetic neurons by intraperitoneal injection of FG in both NT-4 $(+/+)$ and $(-/-)$ animals. Figure $3, A$ and $B$, demonstrates a longitudinal section of the thoracic spinal cord (T7-T10) showing FG-labeled neurons in the IML and LF. Figure $3 C-E$ presents the result of the cell counts of preganglionic sympathetic neurons in spinal cord segments T1-T5, T7-T10, and T10-T12. Segments $\mathrm{T} 1-\mathrm{T} 5$ contain the bulk of preganglionic neurons projecting to the SCG and SG, T7-T10 the majority of preganglionic neurons for the adrenal medulla, and segments T10-T12 most IML neurons projecting to the CG (Fig. 1B) (Strack et al., 1988; Pyner and Coote, 1994). In all spinal cord segments studied, numbers of preganglionic sympathetic neurons were significantly reduced in NT-4-deficient mice compared with wild-type littermates. Reductions were highest in segments T10-T12 $(-30 \%)$, which project 

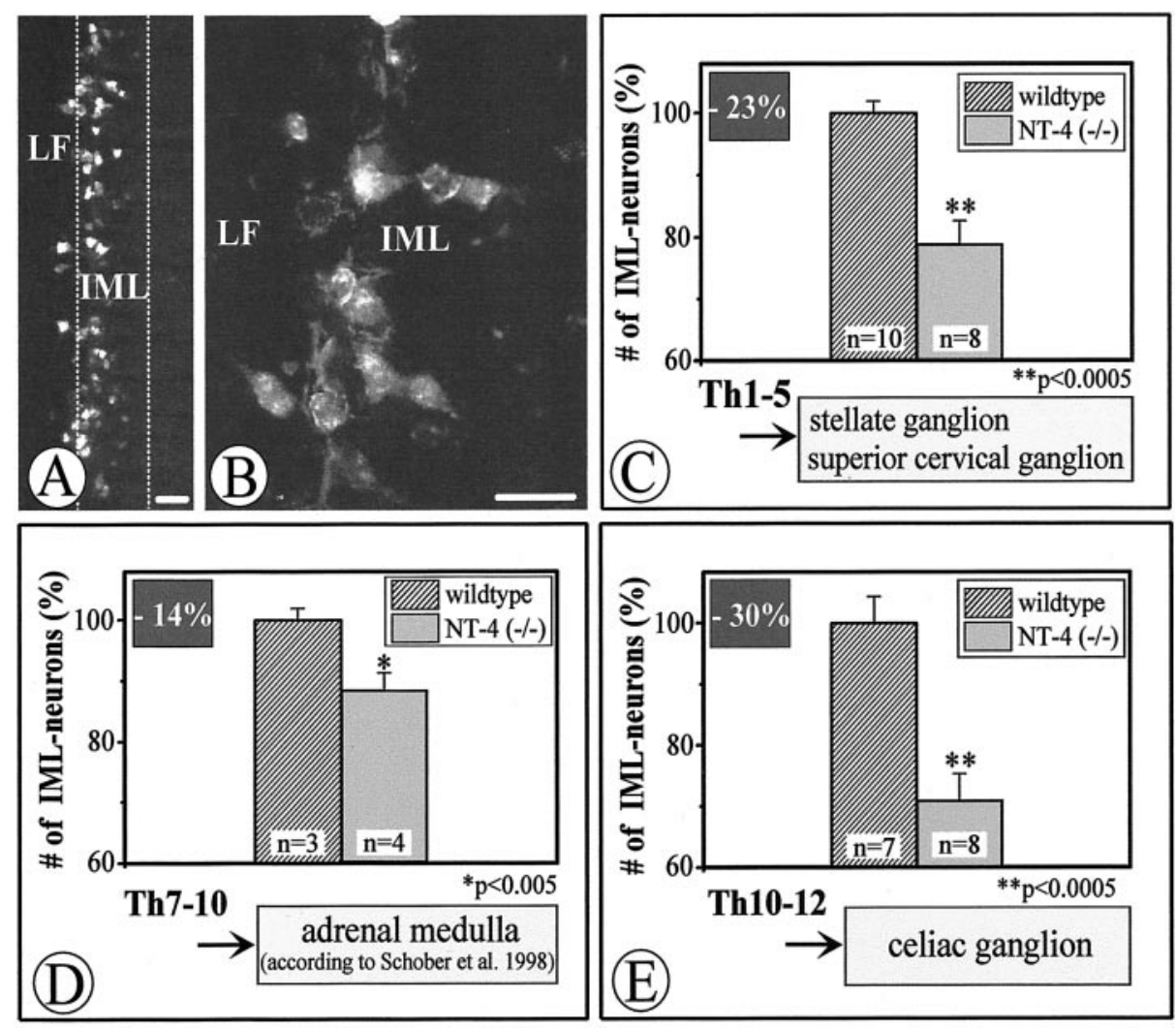

Figure 3. Fluoro-Gold labeling $(A, B)$ and quantitative evaluation $(C-E)$ of IML neurons in wild-type and NT-4-deficient mice. $A$ and $B$ show longitudinal sections through the IML and adjacent LF at T1-T5, displaying FluoroGold-labeled preganglionic sympathetic neurons. $C-E$, Adult mice lacking NT-4 show significant losses of Fluoro-Gold-labeled IML neurons, the extent of which varies in different spinal cord segments. Data are given as mean \pm SEM. $p$ values derived from Student's $t$ test are as indicated. Scale bars, $50 \mu \mathrm{m}$.

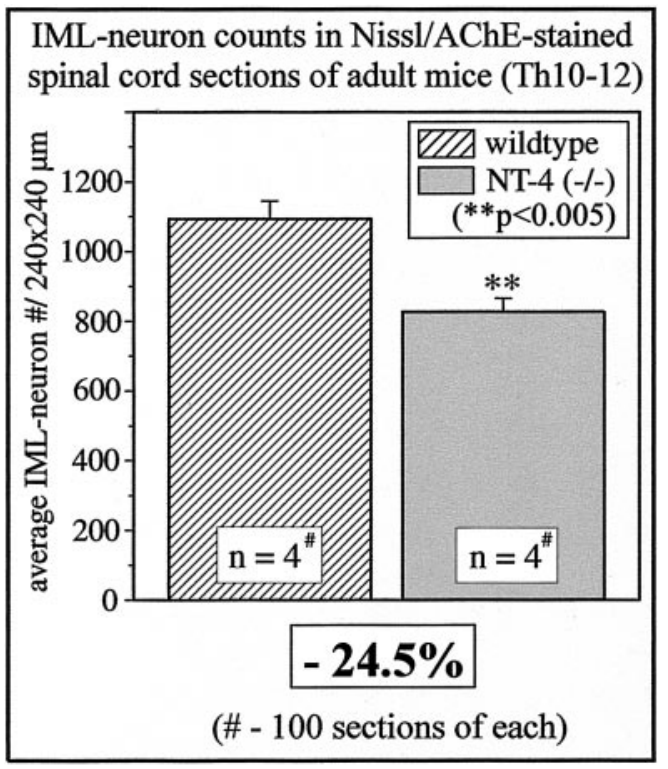

Figure 4. IML neuron counts in Nissl- and AChE-stained spinal cord sections (segments T10-T12) of wild-type and NT-4-deficient mice.

to the CG, and relatively modest in T7-T10 $(-14 \%)$, in which preganglionic neurons for the adrenal medulla are concentrated. Losses of preganglionic neurons at T1-T5 amounted to $23 \%$. Because NT-4 deficiency might compromise Fluoro-Gold labeling of IML neurons without resulting in IML neuron death, we conducted an independent series of experiments counting IML neurons on serial transverse spinal cord sections (segments T10T12) stained by Nissl and AChE methods (Fig. 4). These counts revealed a $24.5 \%$ loss of IML neurons in mutant mice. Together, these data indicate that loss of NT-4 results in a significant numerical deficit in preganglionic sympathetic neurons throughout the spinal cord axis.

\section{Losses of preganglionic sympathetic neurons are not caused by a numerical deficit in postganglionic neurons}

A numerical decrease in preganglionic sympathetic neurons might result from a loss of postganglionic neurons, as has been documented for the NGF-deprived chick embryo, in which destruction of paravertebral ganglia causes severe defects in the columna Therni, an equivalent of the mammalian IML (Oppenheim et al., 1982). We therefore counted neurons in the SCG, the $\mathrm{SG}$, and the CG, as described in Materials and Methods. However, significant differences in numbers of postganglionic neurons comparing NT-4 knock-outs and wild-type littermates were not detected (data not shown).

\section{Numbers of axons in the thoracic sympathetic trunk are decreased in NT-4 (-/-) mice}

To confirm the significant losses of IML neurons in mice lacking NT-4, we counted axon numbers in the CST and TST as an independent measure for IML neuron numbers. As reported previously (Brooks-Fournier and Coggeshall, 1981) and as shown in Figure $1 A$, the majority of axons $(84 \%)$ in the CST represent preganglionic fibers. Similarly, most axons in the TST are preganglionic. As shown above, numbers of postganglionic neurons in the SCG and SG were unaltered in NT-4-deficient mice. Hence, any alterations in numbers of axons in the TST and CST are likely to result from changes in preganglionic axon numbers. Figure $5 A-C$ shows electron micrographs of cross-sections of the TST in an NT-4-deficient mouse and a wild-type littermate. As reported, there were only very few myelinated fibers, because preganglionic sympathetic axons in mouse and rat are mostly unmyelinated 


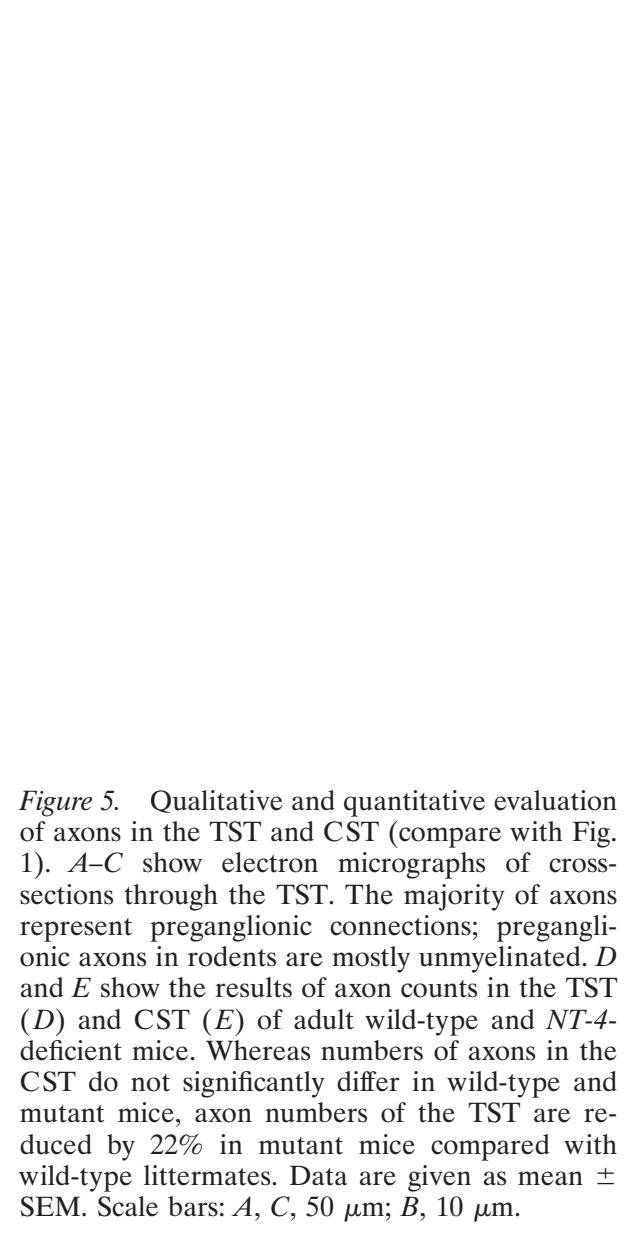

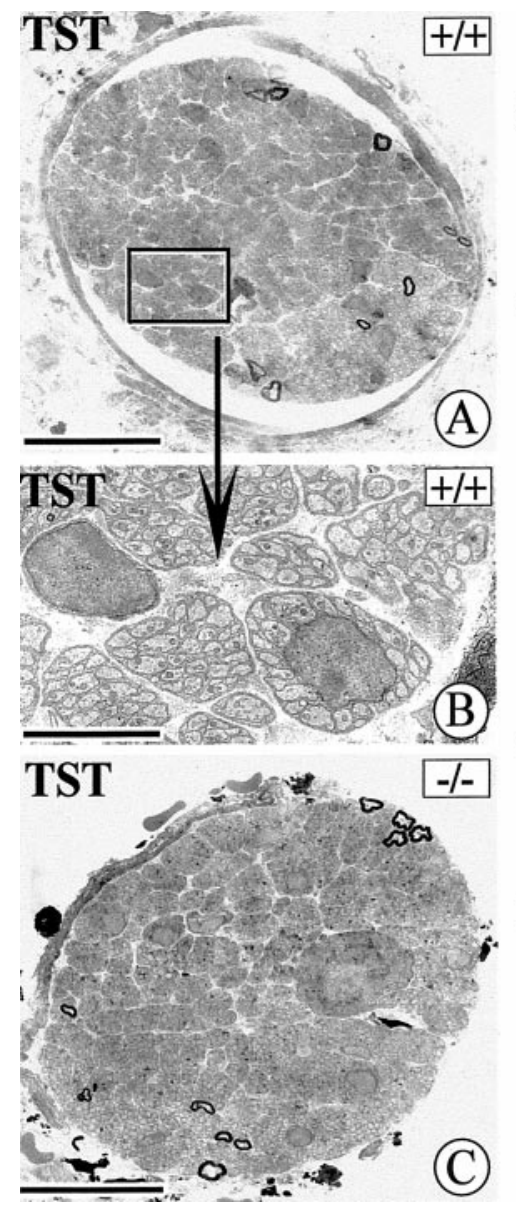
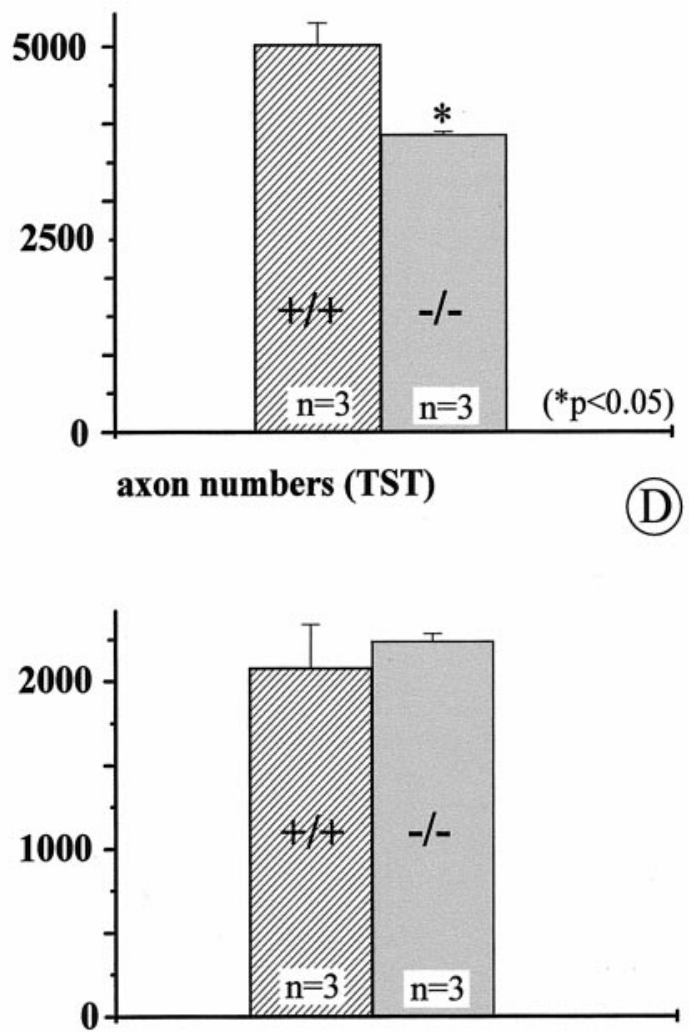

axon numbers (CST)
(Hedger and Webber, 1976). Axon counts revealed a significant $22 \%$ reduction in the number of axons in the TST, close to the $23 \%$ loss of IML neurons in segments T1-T5. Axon numbers in the CST were not altered, suggesting that the specific IML projections to the SCG are probably not affected. Together, these data confirm the reduction in IML neuron numbers seen in $N T$-4-deficient mice but suggest distinct responses of preganglionic neuron subpopulations projecting to the SCG or SG, respectively, to the loss of NT-4.

\section{SV2, a synaptic vesicle antigen, is reduced in the SG and the CG but not in the SCG}

We next investigated whether the reduction in numbers of preganglionic sympathetic neurons seen in NT-4 knock-out mice was accompanied by a loss of a marker for synaptic vesicles in preganglionic axon terminals. SV2 is a transmembrane glycoprotein specific for small synaptic vesicles in the peripheral nervous system and the CNS (Buckley and Kelly, 1985; Feany et al., 1992). Figure 6 reveals the localization of SV2-IR in SCG, SG, and CG. As can be seen in Figure $6 A$, the antigen is localized outside the cell bodies of sympathetic neurons, which only display background IR. Localization of IR is consistent with the presence of SV2 in synaptic endings terminating in their majority on dendrites of postganglionic neurons. Consistent with our counts of IML neurons and preganglionic axons, we found an overt decrease in SV2-IR in the SG (Fig. 6C,D) and CG (Fig. 6E,F) but not in the SCG (Fig. 6A,B).

\section{Losses of preganglionic cell bodies and axons are accompanied by a reduction in numbers of synaptic terminals on postganglionic sympathetic neurons in NT-4 knock-out mice}

To investigate whether reduced SV2-IR resulted from a loss of antigen or a numerical loss of synaptic terminals, we performed EM counts of synaptic terminals in the SG of NT-4 (-/-) and NT-4 (+/+) mice. Synapses were defined by the presence of presynaptic and postsynaptic membrane specializations and accumulations of small synaptic vesicles in the active zone. Figure 7, $B, C$, and $F$, presents qualitative and quantitative data and reveals a significant $28 \%$ reduction in the number of synaptic terminals in NT-4-deficient mice. Again, this reduction matches the losses of preganglionic cell bodies and axons shown above. We also measured the length of presynaptic and postsynaptic membranes in $N T-4(-/-)$ and $N T-4(+/+)$ mice, without detecting significant differences (data not shown).

\section{Losses of preganglionic sympathetic neurons result in a reduction of $\mathrm{TH}$ immunoreactivity and catecholamine content}

Preganglionic synaptic activity crucially regulates transmitter synthesis in postganglionic sympathetic neurons and adrenal chromaffin cells (Thoenen et al., 1969; Viveros, 1975; Zigmond and Ben-Ari, 1977). We therefore investigated TH-IR and catecholamine content in sympathetic ganglia and adrenal medulla of NT-4-deficient mice and wild-type littermates. As shown in Figure 8, TH-IR was not noticeably different in the SCG of knock- 


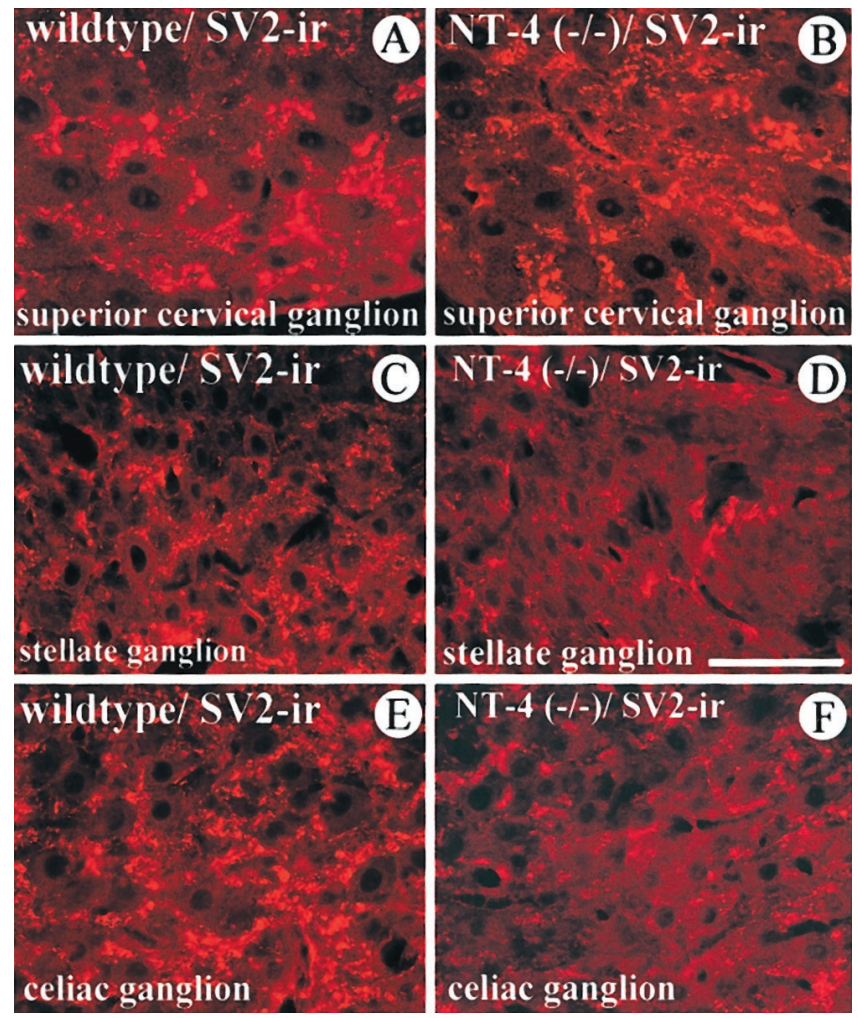

Figure 6. SV2, a synaptic vesicle antigen in preganglionic terminals, is distinctly affected in the SCG $(A, B), \mathrm{SG}(C, D)$, and CG $(E, F)$ of $N T-4$ mutant mice. SV2-IR is localized in structures, presumed axon terminals on dendrites, surrounding the large cell bodies of sympathetic ganglion cells, which exhibit only background fluorescence. SV2-IR is clearly reduced in axon terminals of the SG and CG, but not the SCG, of $N T$-4-deficient mice $(B, D, F)$ compared with wild-type littermates $(A, C$, $E)$. Scale bar, $100 \mu \mathrm{m}$.

out and wild-type mice (Fig. 8A,B). However, TH immunofluorescence was clearly decreased in the $\mathrm{SG}, \mathrm{CG}$, and adrenal medulla of mice lacking NT-4 compared with controls. Thus, these and the above data corroborate the notion that the preganglionic innervation to the SCG of NT-4-deficient mice is not overtly impaired, whereas the loss of preganglionic neurons, which innervate $\mathrm{SG}, \mathrm{CG}$, and adrenal medulla, results in $\mathrm{TH}$ deficiency.

To investigate whether reduction of TH-IR resulted in a decrease in catecholamine levels in the respective ganglia and adrenal gland, we measured catecholamine content by HPLCelectrochemical detection. Figure 9 documents a drastic $64 \%$ loss of noradrenaline in the CG and an $\sim 46 \%$ reduction in adrenaline in the adrenal gland. Surprisingly, in view of the above data, there was also a moderate reduction of noradrenaline in the SCG.

\section{Aggregates of lysosomes in cell bodies and dendrites of neurons in the stellate ganglion}

Comparisons of electron micrographs of neuronal perikarya and dendrites in the SG suggested increased numbers of lysosomes in NT-4 mutant mice (Fig. 7D,E). Although the subsequent counts revealed an apparent tendency for an increase in numbers of lysosomes in both perikarya and dendrites in SG neurons of $N T$-4-deficient mice (Fig. $7 F, G$ ), differences were found not to be statistically significant.
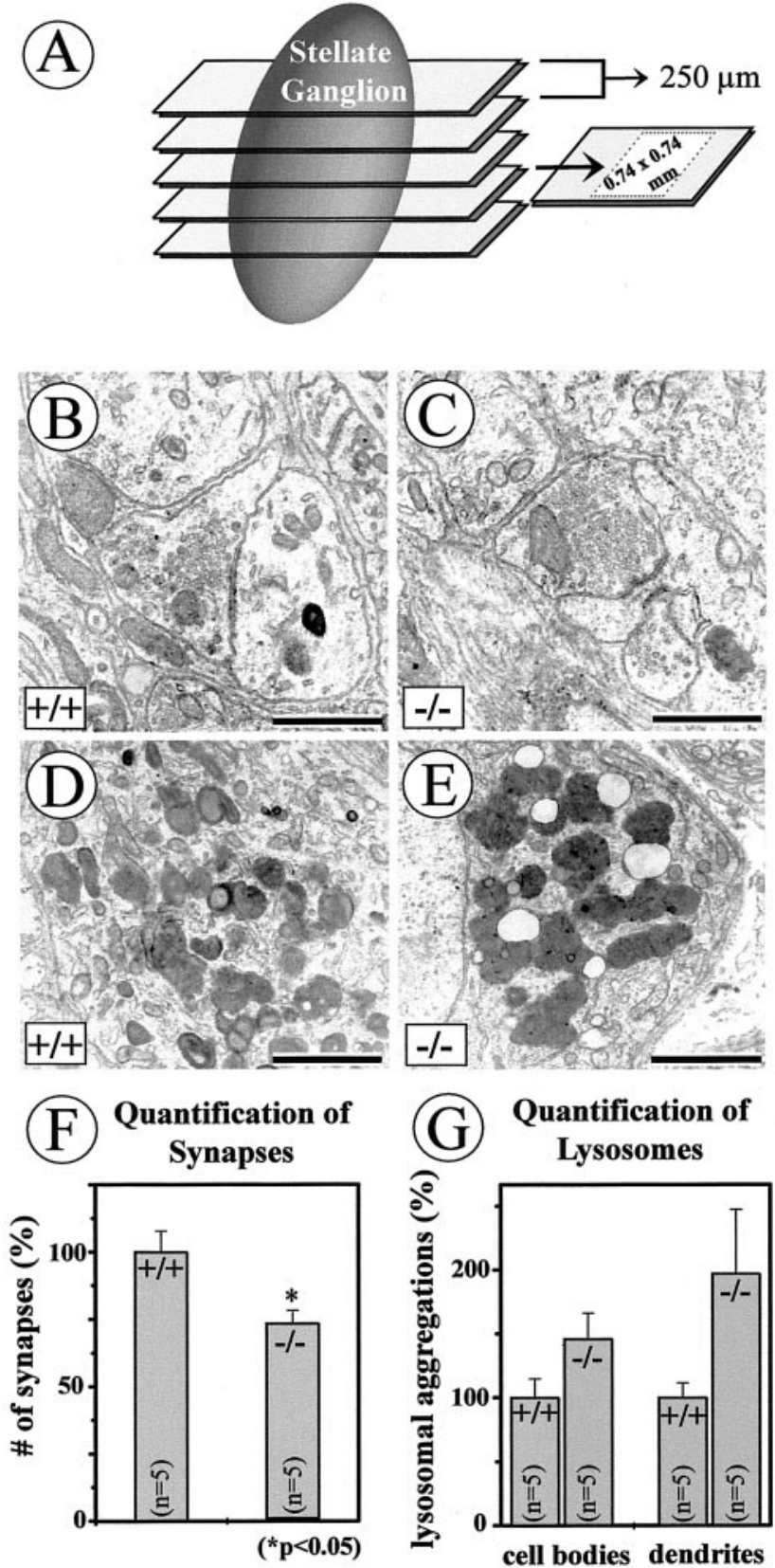

Figure 7. Numbers of synapses $(B, C, F)$ and dense bodies $(D, E, G)$ were evaluated in electron micrographs taken from five sections through the $\mathrm{SG}$, with a distance of $250 \mu \mathrm{m}$, within an area of $0.74 \times 0.74 \mathrm{~mm}$ per section $(A)$ from one NT-4-deficient mouse and one wild-type littermate. Criteria for synapses were presynaptic and postsynaptic membrane specializations and accumulations of synaptic vesicles in the active zone $(B$, $C)$. Although ultrastructural features of synaptic nerve endings were not overtly changed in NT-4 knock-outs compared with wild-type animals $(B$, $C)$, there were significant quantitative differences in numbers of synapses $(F)$. Numbers of lysosomes in neuronal cell bodies and dendrites seemed to be augmented in the NT-4 knock-outs, however, without becoming significant $(G)$. Scale bars: $B, C, 1 \mu \mathrm{m} ; D, E, 2 \mu \mathrm{m}$.

\section{Blood pressure measurements reveal elevated blood pressure levels and enhanced blood pressure variability in NT-4-deficient mice}

Because the sympathetic nervous system is a key component for the maintenance of normal blood pressure levels, the severe deficits in the sympathetic system of mice lacking NT-4 suggested 

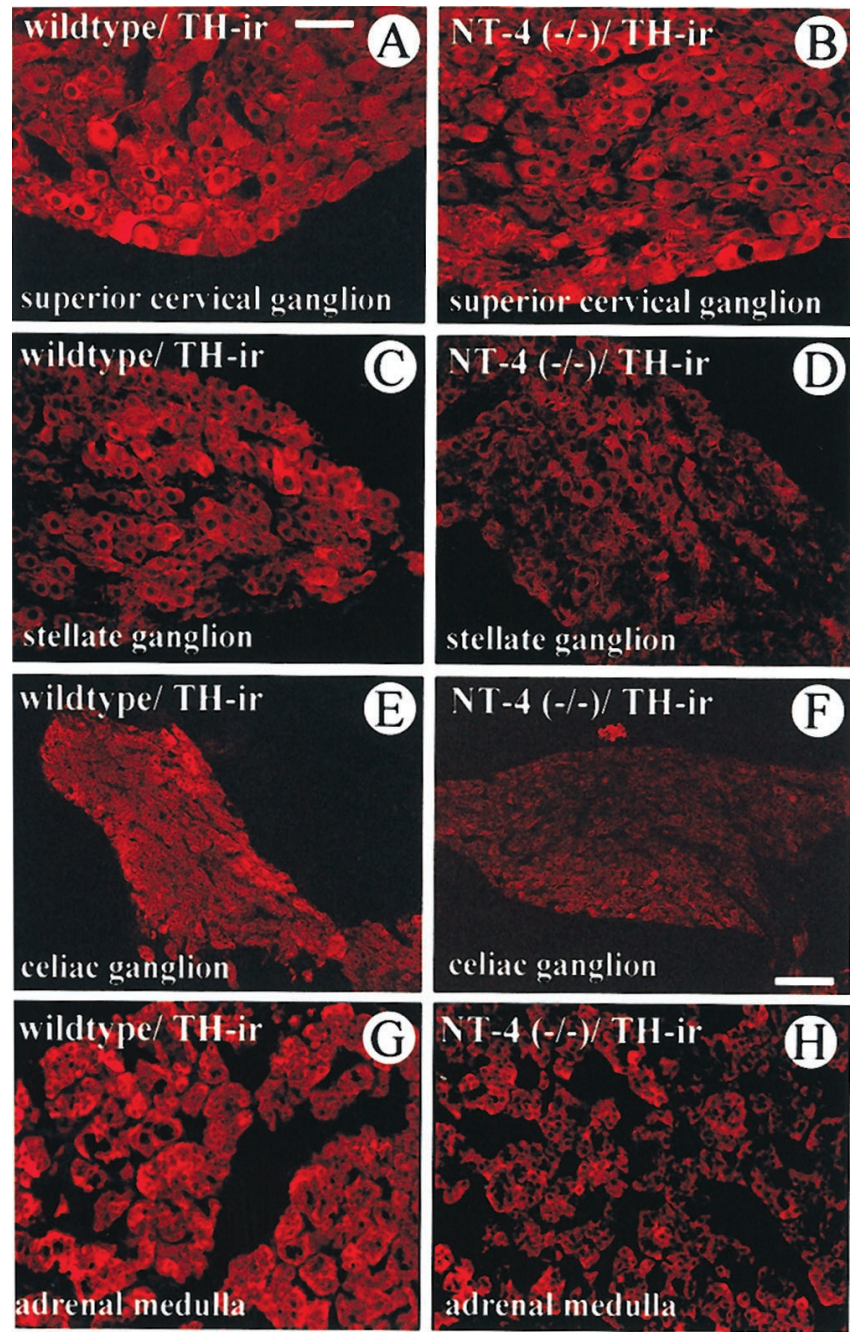

Figure 8. Comparison of TH-IR in the SCG $(A, B), \mathrm{SG}(C, D), \mathrm{CG}(E$, $F)$, and adrenal medulla $(G, H)$ of $N T$-4-deficient mice and wild-type littermates. Although TH-IR is not overtly altered in the SCG, the SG, $\mathrm{CG}$, and adrenal medulla reveal a qualitative reduction of TH staining intensity. Scale bars: $A-D, G, H, 50 \mu \mathrm{m} ; E, F, 100 \mu \mathrm{m}$.

to us that they may display a hypotensive phenotype. We therefore examined baseline blood pressure and heart rate levels in adult unrestrained NT-4-deficient mice. Unexpectedly, these mice were not hypotensive but showed even slightly elevated blood pressure levels compared with wild-type controls (Table 1). This higher resting blood pressure was associated with a highly significant increase of spontaneous blood pressure variability by $\sim 40 \%$ $(p<0.0017)$. Heart rates and heart rate variabilities were not different between wild-type and NT-4-deficient mice.

\section{Losses of IML neurons in NT-4 knock-out mice must occur during or after postnatal development}

To clarify the time period for an NT-4 requirement by preganglionic sympathetic neurons, we counted numbers of IML neurons in spinal cord segments T1-T5 of NT-4 (-/-) and $(+/+)$ mice at $\mathrm{P} 4$. Figure 10 demonstrates that numbers of preganglionic neurons visualized by Nissl staining and AChE histochemistry were not significantly different. This suggests that losses of IML neurons presumably become apparent at later time points in postnatal development.
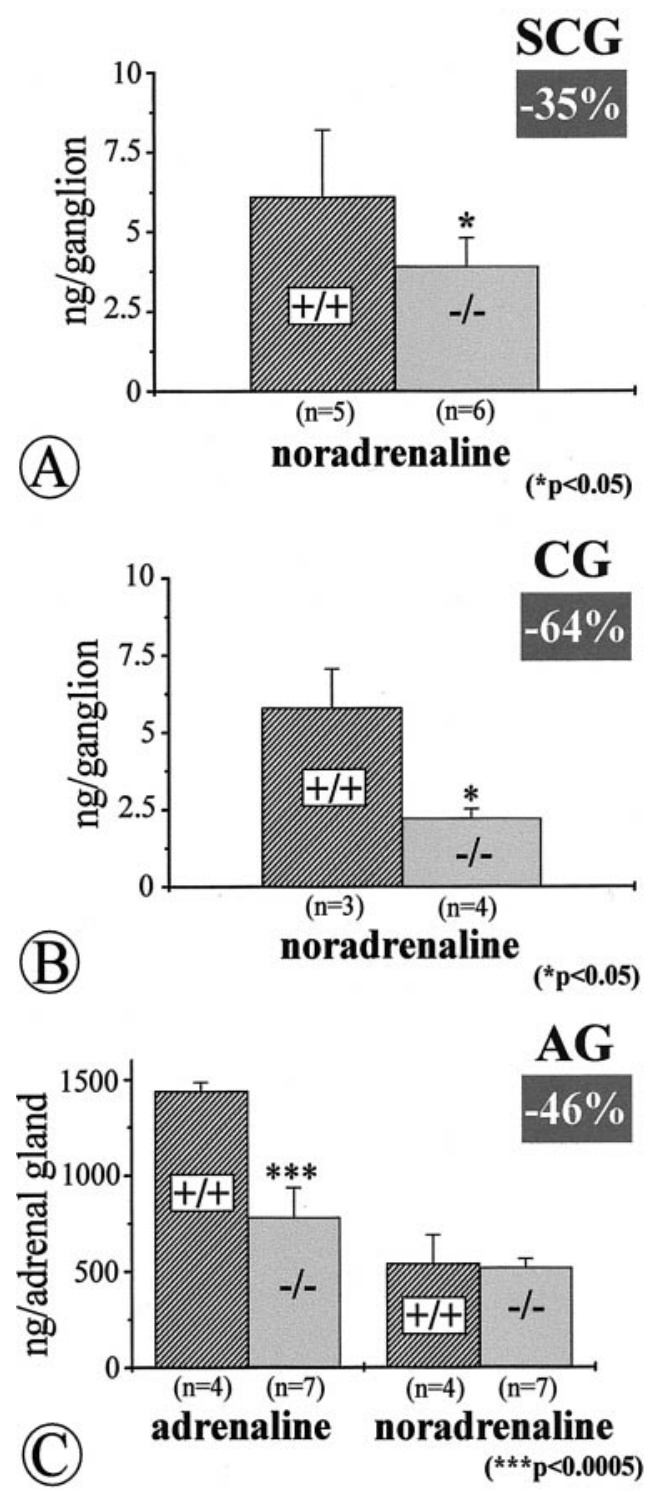

Figure 9. Quantitative determinations of catecholamines by HPLCelectrochemical detection in the SCG $(A), \mathrm{CG}(B)$, and adrenal gland $(A G ; C)$ of $N T$-4-deficient mice and wild-type littermates reveal significant losses of noradrenaline in the SCG and, more severely, in the $\mathrm{CG}$, and losses of adrenaline in the adrenal gland. Data are given as means \pm SEM.

\section{BDNF mRNA is upregulated in the SG and CG, but not SCG, of NT-4-deficient mice}

Because both NT-4 (this study) and BDNF (Causing et al., 1997) occur in sympathetic ganglia, we investigated the possibility of a compensatory upregulation of BDNF mRNA in sympathetic ganglia of NT-4-deficient mice. RT-PCR data shown in Figure 11 suggest a distinct upregulation of BDNF mRNA in the CG and $\mathrm{SG}$, but not SCG, of NT-4-deficient mice. This observation is consistent with the observation that the CG and the SG, but not the SCG, of NT-4-deficient mice receive a reduced preganglionic innervation.

\section{DISCUSSION}

The present study reveals a role for NT-4 for the maintenance of a subset of IML neurons in the spinal cord and their synaptic terminals in paravertebral and prevertebral sympathetic ganglia. 


\begin{tabular}{|c|c|c|c|c|c|}
\hline Genotype & $n$ & $\begin{array}{l}\text { Mean arterial } \\
\text { pressure, } \mathrm{mmHg}\end{array}$ & $\begin{array}{l}\text { SD mean arterial } \\
\text { pressure, } \mathrm{mmHg}\end{array}$ & $\begin{array}{l}\text { Heart rate, } \\
\text { beats } / \mathrm{min}\end{array}$ & $\begin{array}{l}\text { SD heart rate, } \\
\text { beats } / \mathrm{min}\end{array}$ \\
\hline Wild-type & 6 & $105 \pm 1$ & $4.4 \pm 0.4$ & $654 \pm 23$ & $33 \pm 6$ \\
\hline NT-4 (-/-) & 6 & $111 \pm 2^{*}$ & $6.1 \pm 0.2^{* *}$ & $642 \pm 9$ & $43 \pm 2$ \\
\hline
\end{tabular}

Data represent means \pm SEM. $n$, Number of animals. ${ }^{*} p<0.05 ;{ }^{*} p<0.1$ by unpaired, two-tailed Student's $t$ test.

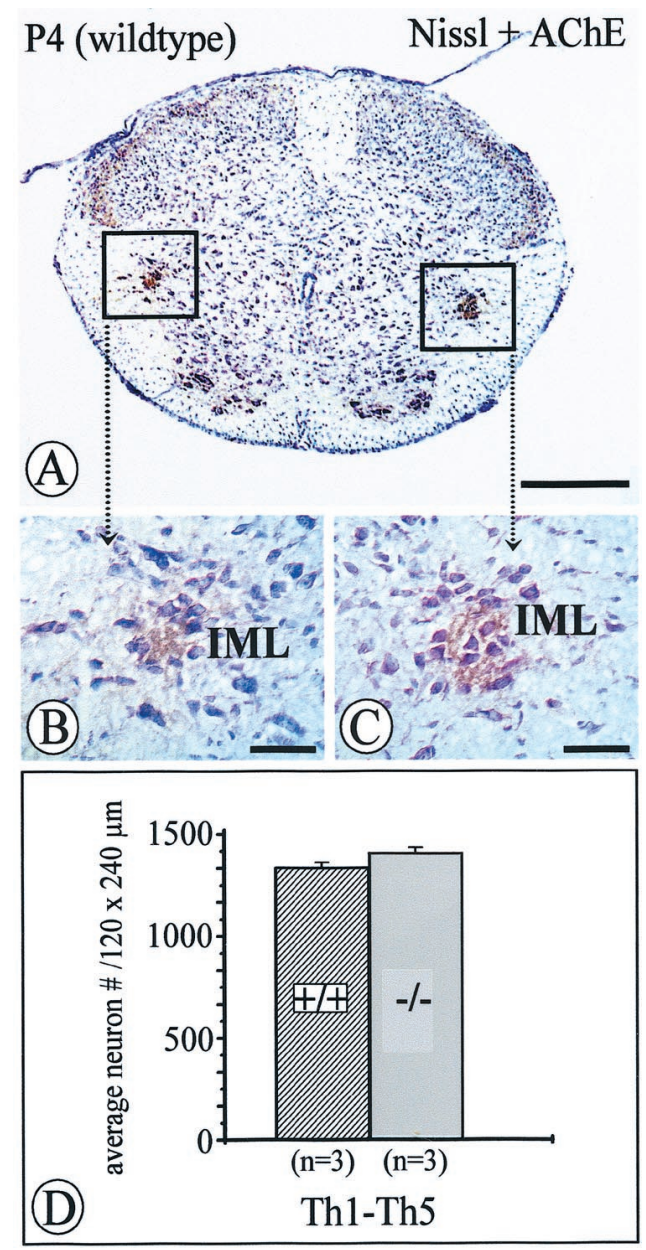

Figure 10. Quantification of acetylcholinesterase-positive, Nissl-stained IML neurons within an area of $120 \times 240 \mu \mathrm{m}$ of the intermediate gray in the spinal cord at P4. Numbers of IML neurons in NT-4-deficient mice $(C$, $D)$ were not significantly reduced compared with controls $(B, D)$ at this age. Data are given as mean \pm SEM. Scale bars: $A, 500 \mu \mathrm{m} ; B, C, 50 \mu \mathrm{m}$.

The NT-4 (-/-) phenotype includes (1) losses of IML neurons throughout the thoracic spinal cord, (2) losses of preganglionic axons in the TST projecting to the SG, (3) decreased IR for the synaptic vesicle marker SV2 in SG and CG, (4) losses of synaptic terminals in the SG, and (5) reduced TH-IR and catecholamine levels in SG and CG but (6) no losses of postganglionic sympathetic neurons. The numerical decrease of IML neurons is not apparent at P4. Because previous counts of IML neurons in P12 TrkB (-/-) mice (Schober et al., 1997) had not revealed a numerical deficit in IML neurons either, we conclude that the losses in IML neurons seen in adult NT-4 mutant mice must occur at later postnatal ages. Sympathetic ganglia of rat and mouse undergo extensive remodeling in the first postnatal month. Numbers of postganglionic neurons decrease significantly during this time period, possibly because of the limitation of trophic supply, such as NGF, from their target areas (Lichtman and Purves, 1980; Purves and Lichtman, 1980). Preganglionic axons still sprout and become rearranged in the adult mouse (Purves et al., 1986). Several lines of evidence indicate that BDNF, NT-4, and their cognate receptor TrkB are crucial in these events. We have reported previously that synaptic terminals on adrenal chromaffin cells are already structurally impaired in P12 TrkB-deficient mice (Schober et al., 1997), the latest time point that can be studied before death of these mutants. At P12, neuronal perikarya are not compromised as yet. This indicates that synaptic terminals of IML neurons may be an early target of TrkB ligands and that subsequent degeneration of IML neurons in the spinal cord might be a secondary event. Further along this line, Causing and coworkers (1997) using transgenic mice have elegantly shown that amounts of BDNF provided by postganglionic sympathetic neurons of the SCG are crucial in regulating synaptic innervation density.

Our data indicate that, in addition to BDNF, NT-4 must be considered to be an important regulator of synaptic innervation to sympathetic neurons. This is also consistent with our observation that BDNF mRNA is compensatorily upregulated in the CG and SG of NT-4-deficient mice. Together, these data implicate that adult mice with a combined loss of NT-4 and BDNF or a loss of TrkB, once they are generated, may reveal a more severe sympathetic ganglia and IML neuron phenotype than NT-4 $(-/-)$ mice but also putative subtle differences. Identification of putative distinct target molecules of BDNF and NT-4 in preganglionic axon terminals and cell bodies could help to define distinct actions of the two neurotrophins.

Although BDNF and NT-4 act through binding to the same TrkB receptor, they have been shown to activate partly distinct signaling cascades. Thus, mutating the shc adaptor binding site on TrkB has revealed diverse effects of BDNF and NT-4 in vivo (Minichiello et al., 1998). Whereas nearly all NT-4-dependent sensory neurons were lost in TrkB ${ }^{\text {shc/shc }}$ mutant mice, BDNFdependent neurons were only modestly affected. Moreover, $\operatorname{TrkB}{ }^{s h c / s h c}$ mutant mice did not show any effects in BDNFdependent differentiation of CNS neurons or in the function of sensory neurons that mediate innocuous touch. Furthermore, knocking the NT-4 gene into the BDNF locus has revealed unique biological activities of NT-4 in vivo (Fan et al., 2000).

Several lines of evidence suggest roles for NT-4 in regulating axon sprouting. Thus, NT-4 administered into striated muscle induced sprouting of intact adult motor nerves. NT-4 is highly expressed in slow, type I muscle fibers, increased by electrical stimulation, and decreased after blockade of neuromuscular transmission. Thus, muscle-derived NT-4 seems to act as an activity-dependent neurotrophic signal for growth and remodeling of adult motor neuron innervation (Funakoshi et al., 1995). Furthermore, we have shown that sympathetic preganglionic cholinergic axons within the adrenomedullectomized rat adrenal gland sprout extensively after replacement of the adrenal medulla 


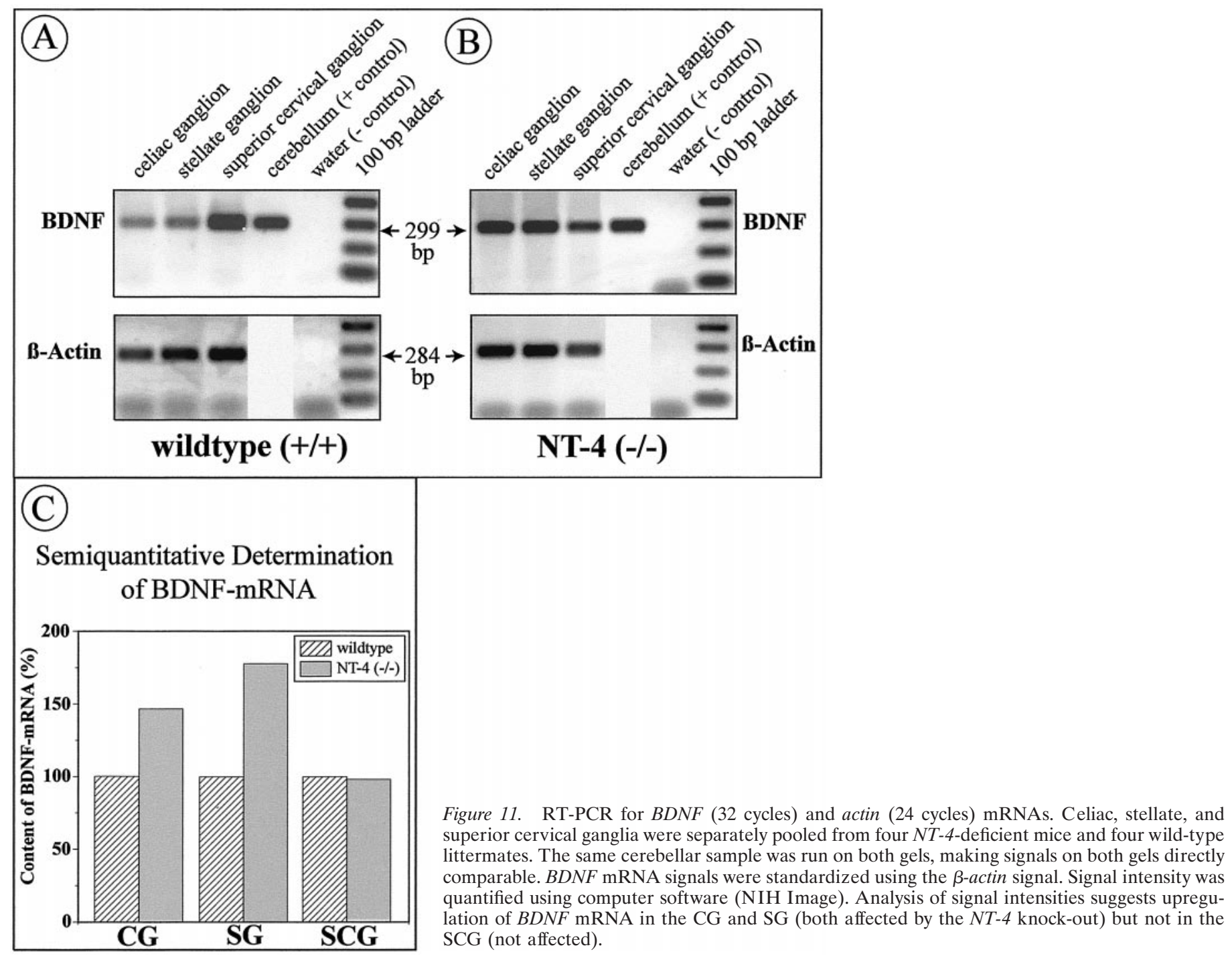

by gel foam containing NT-4 (Schober et al., 1998). It is therefore conceivable that NT-4 secreted by postganglionic sympathetic neurons triggers sprouting of preganglionic axon terminals, thereby regulating numbers of synaptic endings.

If the preganglionic synaptic terminal to sympathetic ganglia is the primary target of NT-4, then changes in postganglionic and preganglionic neuronal cell bodies of NT-4 mutant mice might be indirect. Preganglionic synaptic activity has long been known to regulate transmitter synthesis in postganglionic neurons (Thoenen et al., 1969; Zigmond and Ben-Ari, 1977). Thus, reductions of TH-IR and levels of catecholamines in the SG and $\mathrm{CG}$ may well result from reduced preganglionic input. Our observation of a $35 \%$ loss of catecholamines in the SCG that is not accompanied by structural synaptic deficits suggests that lack of NT-4 may also cause more subtle functional impairment, e.g., with regard to preganglionic impulse flow.

The reduction in the number of IML neurons may be the result of decreased retrograde trophic input from postganglionic neurons. Whether this retrograde factor is NT-4 itself remains to be established. We have not been able to demonstrate retrograde axonal transport of NT-4 in preganglionic sympathetic neurons (Schober et al., 1998). For fibroblast growth factor-2 (FGF-2), it has been shown that components of the FGF receptor-activated signaling cascade rather than FGF-2 itself are retrogradely transported (Hendry et al., 1995a,b). Thus, the failure to document retrograde axonal transport of NT-4 does not disprove this neurotrophin as a trophic factor for IML neurons. Nevertheless, sympathetic postganglionic neurons might support IML neurons by retrograde factors other than neurotrophins, e.g., factors also found in adrenal chromaffin cells, such as FGF-2, ciliary neurotrophic factor, glial cell line-derived neurotrophic factor, and transforming growth factor- $\beta$ (Blottner et al., 1989a,b, 1996; Blottner and Unsicker, 1990; Schober et al., 1999).

Our data concerning the SCG distinguish this sympathetic ganglion in several respects from the SG and CG. First, numbers of axons in the cervical sympathetic trunk were not significantly decreased in NT-4 (-/-) mice. The SCG receives its preganglionic input exclusively through the connection between the SG and SCG; a sympathetic ganglion cervicale medium is absent in rodents (Hedger and Webber, 1976). Postganglionic axons leave the SCG mainly through the nervi jugulares, caroticus internus, caroticus externus, rami laryngopharyngeales, and ramus cardiacus. The CST contains mostly preganglionic axons (84\%), together with sympathetic afferents $(5 \%)$ and few postganglionic fibers $(11 \%)$ (Brooks-Fournier and Coggeshall, 1981). Because numbers of postganglionic cell bodies in the SCG (this study), 
numbers of dorsal root ganglionic neurons (Conover et al., 1995; Liu et al., 1995), and numbers of axons in the CST are not reduced in NT-4-deficient mice, it is likely that the preganglionic input to the SCG is unaltered. This notion is supported by unaltered SV2-IR in preganglionic terminals and TH-IR in postganglionic neurons of the SCG. The reduction in catecholamine content, however, suggests that other features of SCG neuron functions, as transmitter synthesis, may be affected by NT-4 deficiency. In this context, it may be worth noting that the SCG is different from other sympathetic ganglia in several regards, e.g., its origin from the postotic hindbrain neural crest (Durbec et al., 1996). Suggestions to explain the differential sensitivity of SCG and other sympathetic ganglia may include a caudorostral gradient in the NT-4 requirement, possibly linked to the rostrocaudal gradient in the sequence of development of sympathetic ganglia.

In view of the manifold deficits in the sympathetic nervous system, it was surprising that NT-4-deficient mice are not hypotensive. Ganglionic blockade by hexamethonium or inhibition of $\alpha_{1}$-adrenergic transmission by prazosin induces large blood reductions in conscious mice (Janssen et al., 2000), indicating a prominent role of sympathetic tone in murine blood pressure control. The present observations indicate that a lack of NT-4 does not compromise efferent sympathetic control of arterial resistance vessels. The observed higher blood pressure level and enhanced blood pressure variability in NT-4-deficient mice may rather suggest a defect in the afferent limb of the arterial baroreflex. Increased blood pressure variability is a hallmark of baroreceptor deafferentiation (Cowley, 1992). NT-4-deficient mice show substantial reductions in nodose-petrosal sensory neurons, however, without defects in baroreceptor innervation, as seen in mice lacking BDNF (Brady et al., 1999). Thus, the enhanced blood pressure variability in NT-4 (-/-) mice may be caused by a loss of only a small subset of nodose-petrosal sensory neurons, by a defect in the nucleus tractus solitarii, or it may be even unrelated to the histological changes in the afferent sympathetic pathways. Clearly, additional studies are required to determine the cellular basis for the enhanced blood pressure variability in NT-4deficient mice.

In conclusion, the present study is the first demonstration of a physiological relevance of NT-4 for the maintenance of structural and functional integrity of the sympathetic preganglionic and postganglionic circuitry. Thus, NT-4, the "odd one out" in the neurotrophin family (Ibánez, 1996), is gradually broadening its spectrum of functions and gaining importance compared with its fellow neurotrophins.

\section{REFERENCES}

Anderson CR, Edwards SL (1994) Intraperitoneal injections of FluoroGold reliably labels all sympathetic preganglionic neurons in the rat. J Neurosci Methods 53:137-141.

Andrä J, Lojda Z (1986) A histochemical method for the demonstration of acetylcholinesterase activity using semipermeable membranes. Histochemistry 84:575-579.

Barbacid M (1994) The Trk family of neurotrophin receptors. J Neurobiol 25:1386-1403.

Barde YA (1989) Trophic factors and neuronal survival. Neuron 2:1525-1534.

Blottner D, Unsicker K (1990) Maintenance of intermediolateral spinal cord neurons by fibroblast growth factor administered to the medullectomized rat adrenal gland: dependence on intact organ innervation and cellular organization of implants. Eur J Neurosci 2:378-382.

Blottner D, Brüggemann W, Unsicker K (1989a) Ciliary neurotrophic factor supports target-deprived preganglionic sympathetic spinal cord neurons. Neurosci Lett 105:316-320.

Blottner D, Westermann R, Grothe C, Böhlen K, Unsicker K (1989b) Basic fibroblast growth factor in the adrenal gland. Eur J Neurosci $1: 471-478$.
Blottner D, Wolf N, Lachmund A, Flanders KC, Unsicker K (1996) TGF- $\beta$ rescues target deprived preganglionic sympathetic neurons in the spinal cord. Eur J Neurosci 8:202-210.

Brady R, Zaidi SIA, Mayer C, Katz DM (1999) BDNF is a targetderived survival factor for arterial baroreceptor and chemoafferent primary sensory neurons. J Neurosci 19:2131-2142.

Brooks-Fournier R, Coggeshall RE (1981) The ratio of preganglionic axons to postganglionic cells in the sympathetic nervous system of the rat. J Comp Neurol 197:207-216.

Buckley K, Kelly RB (1985) Identification of a transmembrane glycoprotein specific for secretory vesicles of neural and endocrine cells. J Cell Biol 100:1284-1294.

Causing CG, Gloster A, Aloyz R, Bamji SX, Chang E, Fawcett J, Kuchel G, Miller FD (1997) Synaptic innervation density is regulated by neuron-derived BDNF. Neuron 18:257-267.

Coggeshall RE, Chung K, Greenwood D, Hulsebosch CE (1984) An empirical method for converting nucleolar counts to neuronal numbers. J Neurosci Methods 12:125-132.

Conover JC, Erickson JT, Katz DM, Bianchi LM, Poueymirou WT, McClain J, Pan L, Helgren M, Ip NY, Boland P, Friedman B, Wiegand S, Vejsada R, Kato AC, DeChiara TM, Yancopoulos GD (1995) Neuronal deficits, not involving motor neurons, in mice lacking BDNF and/or NT4. Nature 375:235-238.

Cowley AW (1992) Long-term control of arterial blood pressure. Physiol Rev 72:231-300.

Davies AM (2000) Neurotrophins: neurotrophic modulation of neurite growth. Curr Biol 10:R198-R200.

Durbec PL, Larsson-Blomberg LB, Schuchardt A, Costantini F, Pachnis V (1996) Common origin and developmental dependence on c-ret of subsets of enteric and sympathetic neuroblasts. Development 122:349-358.

Erickson JT, Conover JC, Borday V, Champagnat J, Barbacid M, Yancopoulos G, Katz DM (1996) Mice lacking brain-derived neurotrophic factor exhibit visceral sensory neuron losses distinct from mice lacking NT4 and display a severe developmental deficit in control of breathing. J Neurosci 16:5361-5371.

Fan G, Egles C, Sun Y, Minichiello L, Renger JJ, Klein R, Liu G, Jaenisch R (2000) Knocking the NT4 gene into the BDNF locus rescues BDNF deficient mice and reveals distinct NT4 and BDNF activities. Nat Neurosci 3:350-357.

Feany MB, Lee S, Edwards RH, Buckley KM (1992) The synaptic vesicle protein SV2 is a novel type of transmembrane transporter. Cell 70:861-867.

Funakoshi H, Belluardo N, Arenas E, Yamamoto Y, Casabona A, Persson H, Ibánez CF (1995) Muscle-derived neurotrophin-4 as an activity-dependent trophic signal for adult motor neurons. Science 268:1495-1499.

Griesbeck O, Parsadanian AS, Sendtner M, Thoenen H (1995) Expression of neurotrophins in skeletal muscle: quantitative comparison and significance for motoneuron survival and maintenance of function. J Neurosci Res 42:21-33.

Hedger JH, Webber RH (1976) Anatomical study of the cervical sympathetic trunk and ganglia in the albino rat (Mus norvegicus albinus). Acta Anat 96:206-217.

Hendry IA, Johanson SO, Heydon K (1995a) Retrograde axonal transport of the alpha subunit of the GTP-binding protein Gz to the nucleus of sensory neurons. Brain Res 700:157-163.

Hendry IA, Johanson SO, Heydon K (1995b) Developmental signalling. Clin Exp Pharmacol Physiol 22:563-568.

Hyman C, Juhasz M, Jackson C, Wright P, Ip NY, Lindsay RM (1994) Overlapping and distinct actions of the neurotrophins BDNF, NT-3, and NT-4 on cultured dopaminergic and GABAergic neurons of the ventral mesencephalon. J Neurosci 14:335-347.

Ibánez CF (1996) Neurotrophin-4: the odd one out in the neurotrophin family. Neurochem Res 21:787-793.

Ip NY, Ibánez CF, Nye SH, McClain J, Jones PF, Gies DR, Belluscio L, Le Beau MM, Espinosa III R, Squinto SP, Persson, H, Yancopoulos GD (1992) Mammalian neurotrophin-4: structure, chromosomal localization, tissue distribution, and receptor specificity. Proc Natl Acad Sci USA 89:3060-3064.

Ip NY, Li Y, Yancopoulos GD, Lindsay RM (1993) Cultured hippocampal neurons show responses to BDNF, NT-3, and NT-4, but not NGF. J Neurosci 13:3394-3405.

Janssen BJA, Leenders PJA, Smits JFM (2000) Short-term and longterm blood pressure and heart rate variability in the mouse. Am J Physiol 278:R215-R225.

Konigsmark BW (1970) Methods for counting neurons. In: Contemporary research methods in neuroanatomy (Nauta WJH, Ebesson SOE, eds), pp 315-340. Heidelberg: Springer.

Korsching S (1993) The neurotrophic factor concept: a reexamination. J Neurosci 13:2739-2748.

Leibrock J, Lottspeich F, Hohn A, Hofer M, Hengerer B, Masiakowski P, Thoenen H, Barde YA (1989) Molecular cloning and expression of brain-derived neurotrophic factor. Nature 341:149-152. 
Levi-Montalcini R (1987) The nerve growth factor 35 years later. Science 237:1154-1162.

Lichtman JW, Purves D (1980) The elimination of redundant preganglionic innervation to hamster sympathetic ganglion cells in early postnatal life. J Physiol (Lond) 301:213-228.

Liu X, Ernfors P, Wu H, Jaenisch R (1995) Sensory but not motor neuron deficits in mice lacking NT-4 and BDNF. Nature 375:238-241.

Maisonpierre PC, Belluscio L, Squinto S, Ip NY, Furth ME, Lindsay RM, Yancopoulos GD (1990) Neurotrophin-3: a neurotrophic factor related to NGF and BDNF. Science 247:1446-1451.

Mattson DL (1998) Long-term measurement of arterial blood pressure in conscious mice. Am J Physiol 274:R564-R570.

McAllister AK, Katz LC, Lo DC (1999) Neurotrophins and synaptic plasticity. Annu Rev Neurosci 22:295-318.

Minichiello L, Casagranda F, Tatche RS, Stucky CL, Postigo A, Lewin GR, Davies AM, Klein R (1998) Point mutation in trkB causes loss of NT4-dependent neurons without major effects on diverse BDNF responses. Neuron 21:335-345.

Müller TH, Unsicker K (1981) High-performance liquid chromatography with electrochemical detection as highly efficient tool for studying catecholaminergic systems. I. Quantification of noradrenaline, adrenaline and dopamine in cultured adrenal medullary cells. J Neurosci Methods 4:39-52.

Oppenheim RW, Maderdrut JL, Wells DJ (1982) Cell death of motoneurons in the chick embryo spinal cord. VI. Reduction of naturally occurring cell death in the thoracolumbar column of Terni by nerve growth factor. J Comp Neurol 210:174-189.

Purves D, Lichtman JW (1980) Elimination of synapses in the developing nervous system. Science 210:153-157.

Purves D, Hadley RD, Voyvodic JT (1986) Dynamic changes in the dendritic geometry of individual neurons visualized over periods of up to three months in the superior cervical ganglion of living mice. J Neurosci 6:1051-1060.

Pyner S, Coote JH (1994) Evidence that sympathetic preganglionic neurones are arranged in target-specific columns in the thoracic spinal cord of the rat. J Comp Neurol 342:15-22.

Riddle DR, Lo DC, Katz LC (1995) NT-4-mediated rescue of lateral geniculate neurons from effects of monocular deprivation. Nature 378:189-191.

Schober A, Minichiello L, Keller M, Huber K, Layer PG, Roig-López JL, García-Arrarás JE, Klein R, Unsicker K (1997) Reduced acetylcho- linesterase $(\mathrm{AChE})$ activity in adrenal medulla and loss of sympathetic preganglionic neurons in TrkA-deficient, but not TrkB-deficient, mice. J Neurosci 17:891-903.

Schober A, Wolf N, Huber K, Hertel R, Krieglstein K, Minichiello L, Kahane N, Widenfalk J, Kalcheim C, Olson L, Klein R, Lewin GR, Unsicker K (1998) TrkB and neurotrophin-4 are important for development and maintenance of sympathetic preganglionic neurons innervating the adrenal medulla. J Neurosci 18:7272-7284.

Schober A, Hertel R, Arumae U, Farkas L, Jaszai J, Krieglstein K, Saarma M, Unsicker K (1999) Glial cell line-derived neurotrophic factor rescues target-deprived sympathetic spinal cord neurons but requires transforming growth factor-beta as cofactor in vivo. J Neurosci 19:2008-2015.

Smeyne RJ, Klein R, Schnapp A, Long LK, Bryant S, Lewin A, Lira SA, Barbacid M (1994) Severe sensory and sympathetic neuropathies in mice carrying a disrupted Trk/NGF receptor gene. Nature 368:246-248

Snider WD (1994) Functions of the neurotrophins during nervous system development: what the knockouts teaching us. Cell 77:627-638.

Strack AM, Sawyer WB, Marubio LM, Loewy AD (1988) Spinal origin of sympathetic preganglionic neurons in the rat. Brain Res 455:187-191.

Stucky CL, DeChiara T, Lindsay RM, Yancopoulos GD, Koltzenburg M (1998) Neurotrophin 4 is required for the survival of a subclass of hair follicle receptors. J Neurosci 18:7040-7046.

Thoenen H (1972) Surgical, immunological and chemical sympathectomy. Their application in the investigation of the physiology and pharmacology of the sympathetic nervous system. In: Handbook of experimental pharmacology (Blaschko H, Muscholl E, eds), pp 813844. Heidelberg: Springer.

Thoenen H, Mueller RH, Axelrod J (1969) Trans-synaptic induction of adrenal tyrosine hydroxylase. J Pharmacol Exp Ther 169:249-254.

Timmusk T, Belluardo N, Metsis M, Persson H (1993) Widespread and developmentally regulated expression of neurotrophin-4 mRNA in rat brain and peripheral tissue. Eur J Neurosci 5:605-613.

Viveros OH (1975) Mechanism of secretion of catecholamines from adrenal medulla. In: Handbook of physiology, Sec 7, Endocrinology, Vol VI, Adrenal Gland (Blaschko H, Sayers G, Smith DA, eds), pp 389-426. Washington, DC: American Physiological Society.

Zigmond RE, Ben-Ari Y (1977) Electrical stimulation of preganglionic nerve increases tyrosine hydroxylase. Proc Natl Acad Sci USA 74:30783080 . 